\title{
Şeffaflı̆̆1 Arttırmaya Yönelik Mekanizmalar ve Finansal Başarının Şeffaflık Üzerindeki Etkisi: BIST XKURY'de Bir Araştırma ${ }^{1}$
}

\author{
Mustafa MORTAȘ² ve Serhat ȘAMIL ${ }^{3}$
}

\section{$\ddot{\mathrm{O} z}$}

Çalışmada şeffaflığı arttıran mekanizmalar teorik olarak ele alınmakta ve finansal başarının şeffaf olma üzerinde etkisi olup olmadığı araştırılmaktadır. Öncelikli olarak muhasebe/finansal raporlama standartları ve denetim standartları açısından işletmelerin şeffaflığ ve daha sonra kurumsal yönetim açısından şeffaflık ve kamuyu aydınlatma konuları ele alınmıştır. Daha sonra ise, hem BIST Kurumsal Yönetim Endeksinde hem de BIST 100 Endeksinde işlem gören işletmelerin 5 yılllı finansal verileri (2011-2015) kullanılarak TOPSIS yöntemi ile finansal performansları standart ve tek bir ölçü haline getirilmiştir. Kamuyu Aydınlatma ve Şeffaflık Notları (KASN), İşletme Büyüklükleri, İşletme Borçlanma Oranları ve İşletme Yaşları araştırmanın diğer değişkenleridir. Yapılan analizler sonucunda, işletmelerin finansal başarııının, işletme büyüklüklerinin, kamuyu aydınlatma ve şeffaflık uygulamaları üzerinde pozitif anlamlı bir etkisinin olduğu, borçlanma oranlarının ise; işletmelerin kamuyu aydınlatma ve şeffaflık uygulamalarının üzerinde anlamlı negatif etkisi olduğu görülmüştür. Firma yaşının ise, kamuyu aydınlatma ve şeffaflık uygulaması üzerinde pozitif ancak anlamlı olmayan etkisi olduğu görülmüştür.

Anabtar Kelimeler: Muhasebe/Finansal Raporlama Standartları, Șeffaflık, TOPSIS, Panel Veri Analizi

The Mechanisms for Increasing Transparency and the Impact of Financial Success on Transparency: A Research in BIST XKURY

\section{Abstract}

The study deals with the mechanisms increasing transparency and the issue whether financial success has impact on transparency or not is investigated. Firstly transparency of companies in terms of accounting/financial reporting standards and auditing standards and then transparency and public disclosure in terms of corporate governance were discussed. Afterwards, financial success of firms (being dealt in both BIST XKURY and BIST 100) has been calculated by TOPSIS Method by using the five-year financial data (2011-2015). Public Disclosure and Transparency Notes (KASN), Business Sizes, Business Borrowing Ratios and Age of Business are other variables of the research. As a result of the analyzes, the financial success of enterprises, business sizes, public disclosure and transparency applications have a positive significant effect on the borrowing rates; It has been observed that enterprises have a significant negative effect on public disclosure and transparency practices. On the other hand, firm age has a positive but not significant effect on public disclosure and transparency.

Key Words: Accounting/Financial Reporting Standards, Transparency, TOPSIS, Panel Data Analysis

\section{Atıf İçin / Please Cite As:}

Mortaş, M. ve Şamil, S. (2020). Şeffaflığ1 arttırmaya yönelik mekanizmalar ve finansal başarının şeffaflık üzerindeki etkisi: BIST XKURY'de bir araştırma. Manas Sosyal Arastırmalar Dergisi, 9(1), 341-359.

\footnotetext{
${ }^{1}$ Bu çalışma Karamanoğlu Mehmetbey Üniversitesi Bilimsel Araştırma Projeleri Koordinatörlügü tarafindan desteklenen 02-M16No'lu proje verilerinden elde edilerek hazırlanmıştır.

2 Dr. Öğr. Üyesi - Karamanoğlu Mehmetbey Üniversitesi İktisadi ve İdari Bilimler Fakültesi, İşletme Bölümü, mmortas@kmu.edu.tr - ORCID: 0000-0002-9759-3038

3 Arş. Gör. - Karamanoğlu Mehmetbey Üniversitesi İktisadi ve İdari Bilimler Fakültesi, İşletme Bölümü, sesamil@kmu.edu.tr ORCID: 0000-0003-4075-9268
} 


\section{Giriş}

Her geçen gün daha hızlı ve kapsamlı işlemler yapmaya imkân tanıyan içinde bulunduğumuz teknoloji çağında ekonomik faaliyetler ülke sınırlarını ortadan kaldırmıştı. Buna bağlı olarak ortaya çıkan uluslararası antlaşmalar kapsamında işletmelerin uymak durumunda olduğu ticari faaliyetlerini, düzenleyen hukuksal düzenlemeler yapılmıştır. Bu düzenlemeler, sürdürülebilirlik sağlanması adına elzem bir ihtiyaç haline gelmiştir. İşletmelerin sadece faaliyetleri küreselleşmemiş aynı zamanda ortaklık yapısı/yönetim yapısı olarak da küreselleşmişlerdir.

Yaşanan küreselleşme ile birlikte ülke sınırları giderek önemini kaybederken finansal piyasalarda fon transferi sınır tanımadan hareket etmektedir. Günümüzde işletmeler finansman ihtiyaçlarını karşılamada ulusal piyasa ile sınırlı kalmamakta, uluslararası alandaki sermaye hareketlerinden pay almaya çalışmaktadır. Fon arz edici olan yatırımcıların seçenekleri artmış ve uluslararası bir nitelik kazanmıştır. Bu gelişmelerle birlikte piyasalarda yatırımcıların diğer menfaat sahipleriyle birlikte haklarının korunması amacıyla güvenilir sistemlerin oluşturulması gereği ortaya çıkmıştır.

Muhasebe ve Finansal Raporlama Standartları uygulamalarında olduğu gibi küreselleşmenin getirdiği işletme/muhasebe sorunlarını ortadan kaldırmak amacıyla hem yönetimsel hem muhasebe açısından hem de tüm paydaşlar açsindan yeterli ve güvenilir "yönetsel ve finansal bilginin" sağlanabilmesi, yani; işletmelerin hesapverebilir, şeffaf ve kurumsal bir yapıya kavuşması için Kurumsal Yönetim İlkeleri geliştirilmiştir. Gerek kurumların gerekse şirketlerin yönetimlerinde oluşturacakları sistemlerin herkes tarafindan kabul edilen standart ve ilkeleri bulunmaktadır. Sözü edilen standartlar ve ilkeler; küresel bir ifadeyle "Kurumsal Yönetim İlkeleri” olarak tanımlanmaktadır.

\section{Kurumsal Yönetim ve Muhasebe/Finansal Raporlama Standartları ile Denetim Standartları Açısından İşletmelerin Şeffaflığı}

İşletmelerin, iç ve dış paydaşlarına karşı şeffaflığının sağlanabilmesi için öncelikli olarak kurumsal yönetim ilkelerini benimsemiş ve uyguluyor olması gelmektedir. Bununla birlikte işletmelerin güvenilir ve karşılaştırılabilir finansal raporların oluşturulabilir olması için muhasebe/finansal raporlama standartlarını uygun muhasebe faaliyetleri yürütüyor olması gerektiği belirtilebilir. Diğer bir durum ise; muhasebe/finansal raporlama standartlarına uygun hazırlanmış olan finansal raporların doğruluğu ve güvenirliliği için söz konusu finansal raporların bağımsız denetimden geçmiş olması gerekmektedir.

\section{Muhasebe/Finansal Raporlama Standartları ve Denetim Standartları Açısından İşletmelerin Şeffaflı̆̆1}

Düzenli, güvenilir ve karşılaştırlabilir bilgi olmaksızın, yatırımcıların işletmenin kurumsal resmini değerlendirmeleri ve buna bağlı olarak çeşitli yatırım kararları arasında sağlıklı tercih yapmaları mümkün değildir. Kamunun aydınlatılması ve şeffaflık, piyasa ekonomisinde şirketlerin denetimi ve gözetiminde kullanılan en önemli araçtır. Bu durum aynı zamanda kamuoyunun, işletmelerin performansının yanında, yapıları, faaliyetleri ve politikaları hakkında da bilgi sahibi olmasına imkân sağlar. Bu nedenlerden dolayı, kamuoyuna açıklanacak bilgiler, sıkı kurallara bağlanmalıdır. Diğer bir durum ise, işletme tarafindan kamuoyuna yapılacak açıklamaların, işletmenin menfaatlerine zarar vermemesi ve işletme hakkındaki ticari sırların kamuya açıklanmasına yol açmaması gerekmektedir. Etkin bir kamuyu aydınlatma sağlanabilmesi için, işletmeler üzerinde kanunlar ve düzenleyici otoriteler aracıllı̆̆yla yasal ve idari bask1 yapılması tek başına yeterli olmayacaktır. İşletmelerin, kamuyu aydınlatmanın bir yükümlülükten ziyade daha uzun vadeli ve kalıcı sermaye çekebilmenin en etkili yolu olabileceğini görmeleri gerekmektedir. Daha uzun vadeli ve sabırlı bir şekilde sermaye çekmenin yolu, iç ve dış yatırımcılara gerekli güvenin sağlanmasından geçmektedir (Mortaş, 2011, s. 6). Bu bakımdan güvenin tesis edilebilmesi için, işletmenin şeffaf ve hesap verebilir niteliğe sahip olması gerekmektedir.

OECD tarafindan ulusal hükümetler, ilgili uluslararası kuruluşlar ve özel sektör ile birlikte 1999 'da hazırlanan ve son olarak Eylül 2015’te revize edilen Kurumsal Yönetim İlkeleri'nde şeffaflik; 2004 yllında revize edildiği tarihten buyana kamuya açıklama (disclosure) kavramı ile birlikte ele alınmaktadır. Söz konusu ilkelere göre; Kamuyu Aydınlatma ve Şeffaflık, kurumsal yönetim çerçevesinin içinde yer alan ilkelerden biri olup, ilkelerde işletmelerin finansal durumu, performansı, mülkiyet yapısı da dahil olmak üzere, işletmelerle ilgili bütün konularda doğru ve zamanında açıklama yapılmasının sağlanması amaçlanmaktadır. Bu durum, dünya genelinde karar alıcılar, yatıımcılar ve diğer işletme paydaşları tarafindan ilkeleri, uluslararası temel bir kaynak haline getirmiştir (OECD, Kurumsal Yönetim İlkeleri, 
Eylül 2015). Şeffaflık ve Kamuyu Aydınlatma ilkesi, yukarıda ifade edilenler çerçevesinde dikkate alındığında son yıllarda sermaye piyasasında önemini daha da artırmıştır.

Şeffaflı̆̆ın sağlanmasında kamuyu bilgilendirmeleri tek başına yeterli görülmemekte, ayrıca sıkı muhasebe kurallarının oluşturulmasına ihtiyaç duyulmaktadır. Bilginin güvenilir ve karşılaştırılabilir olması, firmaların faaliyetlerinin ve risk profillerinin eşit koşullarda değerlendirilmesine imkan sağlayacak olan etkin kural ve standartlara dayalı muhasebe uygulamalarının var olmasıyla yakından ilisskilidir (Türkiye Bankalar Birliği Bankacılık ve Araştırma Grubu, Ocak 2002).

Şeffaflık ve kamuyu aydınlatmanın işletme düzeyinde benimsenmesi, yatırımcı haklarının korunması ve toplum güveninin kazanılması açısından önemlilik arz etmektedir. İşletmeler uluslararası alanda kabul görmüş rehber niteliğindeki ilkeleri izleyerek, kurumsal şeffaflık derecelerini artırabilmektedirler. Kurumsal şeffaflık ve kamuyu aydınlatma, muhasebe uygulamaları ile doğrudan ilişkilidir. Öyle ki, güvenilir, kapsaml, ihtiyaca uygun ve karşılaştırılabilir finansal tablolar ancak uluslararası alanda kabul görmüş muhasebe/finansal raporlama standartlarnnın benimsenmesi ile ortaya konulabilmektedir (Arsoy, 2008, s. 17).

Finansal Raporlama Standartlarının anayasası konumunda olan, "Finansal Raporlamaya İlişkin Kavramsal Çerçeve"de, faydalı bilginin niteliksel özellikleri başlı̆ı altındaki ilk madde (KGK, Finansal Raporlamaya İlişkin Kavramsal Çerçeve): "Temel niteliksel özellikler, ihtiyaca uygunluk ve gerçeğe uygun șekilde sunumdur" şeklinde belirtilerek, finansal raporlar için kesin bir çizgi çizmiştir. Finansal tabloların, finansal tablo kullanıcıları için karar almalarına yardımcı şeffaf ve kamuyu aydınlatıcı bilgi içermesi gerektiği, özellikle temel niteliksel özelliklerde vurgulanmaktadır. Zira gerçeğe uygun sunum özelliği: "Finansal bilginin kullamcolara faydah olabilmesi için ilgili olayları sunması yeterli değildir. Ayruca açılklamay amaçladiğ ekonomik olaylar gerçeğe uygun bir şekilde sunmalidrr. Gerçeğe uygun bir sunumun, tam anlamiyla săglanabilmesi için üç özelliğe sahip olmast gerekir. Buna göre sunum tam, tarafsı ve hatasız olmalıdır" şeklinde Kavramsal Çerçeve'de tanımlanmaktadır. Hatasız olmakla kalmayıp aynı zamanda tam ve tarafsız olması gerektiği de ciddi şekilde vurgulanmaktadır. Böylelikle kamuyu aydınlatıcı ve şeffaf bir finansal tablonun kamuoyuna açıklanabileceği standartların tamamı için genelleştirilmiştir.

Kavramsal çerçevede tam bir sunum; ekonomik olayın bir kullanıcı tarafindan anlaşılması için tanımlamalar ve açıklamalar da dâhil olmak üzere gerekli tüm bilgileri içermesi gerektiği belirtilmiştir. Diğer taraftan TMS-1Finansal Tabloların Sunuluşu Standardında (KGK, TMS 1 Finansal Tabloların Sunuluşu Standardı); Finansal tabloların amacı belirtilirken, geniş bir kullanıcı kitlesinin ekonomik kararlar almalarına yardımcı olan işletmenin finansal durumu, finansal performansı ve nakit akışları hakkında bilgi sağlamak olduğu da belirtilmiştir. Diğer taraftan yine aynı standartta, finansal tabloların yöneticilerin, kendilerine emanet edilen kaynakları ne etkinlikte kullandıklarını da göstermesi gerektiği de belirtilmiştir. Esasen Muhasebe ve Finansal Raporlama Standartlarının tam ve doğru biçimde uygulanması durumunda finansal tabloların şeffaf ve kamuyu aydınlatıcı bilgiye sahip olacağı ve hesap verebilir niteliğe kavuşacağı vurgulanmaya çalışıldığ ifade edilebilir.

Yukarıdaki paragraflarda ele alındığı gibi işletmelerin daha şeffaf, kamuyu aydınlatan, hesap verebilir nitelikte finansal bilginin sunumu (disclosure) için Muhasebe/Finansal Raporlama Standartlarının uygulanması gerektiği belirtilmektedir. Diğer bir ifade ile Muhasebe/Finansal Raporlama Standartlarını uygulayan bir işletmenin finansal raporların gerçeğe uygun, zamanında ve karşılaştırılabilir finansal bilgi sunmakla birlikte, finansal bilgi kullanıcıları açısından sunulan bilginin güvenirlilik kısmı eksik kaldığı ifade edilebilir.

Finansal raporların güvenirlilik düzeyi ise bağımsız denetim yolu ile ifade edilebilecektir. Diğer bir ifade ile sunulan finansal raporların ve faaliyet raporlarının şeffaf ve kamuyu aydınlatabilir nitelikte olup olmadığının belgelenebilmesi ve işletme paydaşlarının güveninin sağlanabilmesi için ihtiyaç duyulan diğer bir önemli unsur; bağımsız denetim raporudur. Bağımsız denetçi, denetim faaliyetlerinin sürdürülmesi ve raporun hazırlanması için Bağımsız Denetim Standartlarını ve Genel Kabul Görmüş Denetim Standartlarını rehber edinmektedir.

Özellikle muhasebe alanında çalışan meslek mensupları, bilim insanları tarafından muhasebe ve denetim kavramlarının birbirleriyle yakın ilişki içinde olduğu bilinmektedir. Çünkü muhasebesiz denetim olmaz ve denetimin gerekliliği muhasebenin gerekliliğini beraberinde getirmektedir. Kisaca ifade etmek gerekir ise; muhasebesiz denetleme dayanaksız; denetimsiz muhasebe ise sağlamasızdır (Uzay vd, 2009, s. 127).Denetim faaliyetinin yerine getirilmesi ise, muhasebe uygulamalarının güvenirliliği ve standartların 
korunmasını birtakım normlar ve kodlar dahilinde gerçekleştir. Bu önemli görevin yerine getirilmesi kurum içi ve kurum dışı denetçilerin ve denetim komitelerinin etkinliği ve etkililiğinin gücü ile ilişkilidir. $\mathrm{Bu}$ sebeple denetim yapısının, muhasebe kalitesinde, finansal şeffaflı̆̆ın güçlenmesinde ve başarıya ulaşmasında başrol oynadığı belirtilebilir (Abay, 2013, s. 166).

Yaşanan muhasebe skandalları içerisinde en önemlilerinden biri Enron olayıdır. Enron olayı ile birlikte dünyanın en büyük denetim firmalarından olan Arthur Anderson denetim şirketinin de ortaya çıkan yolsuzlukta payının oluşu, denetime olan güvenin de zedelenmesine sebep olmuştur. Çünkü denetimin temel amaçlarından birisi, yukarıda da ifade edildiği gibi finansal tablolara güvenilirlik kazandırmaktır. Diğer bir ifadeyle denetim bir güvence hizmetidir. Benzer bir durum, Türkiye'de İmar Bankası olayında kendini göstermiş ve yatırımcıların piyasalara olan güveninin zedelenmesine neden olmuştur. Denetim faaliyetinin en temel amaçlarından biri, hatalı veya hileli bilgilerin neden olabileceği riski azaltmak, finansal raporlamalarda yöneticilerin yapabilecekleri usulsüzlükleri en aza indirmektir. İşletmelerdeki hile ve usulsüzlüklerin denetim kalitesinin zayıf olduğu durumlarda ortaya çıktı̆̆1 bilinmektedir (Terzi vd, 2014, s. 194).

İşletmelerin piyasada kalabilmeleri, ancak dürüst ve güvenilir bir yönetim anlayışı ile mümkün olabilecektir. Bu ise, şeffaflık, hesap verebilirlilik, sorumluluk ve adillik gibi temel ilkeleri içerisinde barındıran ve yönetim şekli olan "kurumsal yönetim" ile sağlanabilmektedir. Yaşanan finansal krizlerin ve muhasebe skandallarının en önemli sebeplerinden biri; yanlış yönetim politikaları ve finansal tablolarda yapılan yolsuzluklardır. Söz konusu olumsuzluklar işletme tarafindan, kurumsal yönetimi tam manasıyla uygulaması ve bağımsız denetim firmalarının işletme finansal tablolarını gerçekçi ve dürüst bir şekilde denetlemesi ile giderilebilecektir. Finansal tabloların hata ve yanlışlık içerme ihtimali, finansal tablolardaki bilgilerden faydalanacakların işletme yönetiminden gelen bilgilere güvenmelerini ve bu bilgileri esas alarak karar almalarını zorlaştırmaktadır. Finansal bilgi kullanıcılarının karar verme sürecinde yararlandıkları finansal ve finansal olmayan bilginin güvenilirliğinin ve doğruluğunun saptanmasında bağımsız denetim önemli bir görev üstlenmiştir.

\section{Kurumsal Yönetim Kapsamında Şeffaflık}

Kurumsal yönetimin tüm dünyada ve akademik alanda tartışılmaya başlanmasında iki temel gelişmenin önemli şekilde rol oynadığ1 belirtilebilir. İlk olarak; küreselleşme ve finansal serbestleşme, şirketlere uluslararası piyasalarda yeni firsatların ve rekabet ortamının önünü açarken, şirketlerin geleneksel finansman kaynaklarının yanında, yeni finansman imkanlarına ihtiyacını da ortaya çıkarmıştır. Büyüyen şirket yapılarından kaynaklanan bu durum, sahiplik ve kontrol ayrımını ortaya çıkartmış ve şirketlerin farklı paydaşlara yönelik sorunlarını da ortaya çıkarmıştır. Bu gelişmeler anonim şirketleri riske açık hale getirirken, şirket içi yolsuzluklar ve kötü yönetimden kaynaklanan iflaslarında artmasına neden olmuştur (Tuna, 2013, s. 5). Küresel anlamda kurumsal yönetim kavramının hızlı gelişimi ülkemizde de yerini bulmuş ve söz konusu kavram hızlı bir şekilde işletme bilgisi olarak ülkemizde yeniden üretilmiştir. Daha sağlıklı ekonomiler, sürdürülebilir kalkınma, şeffaf bir ekonominin varlığı ve ekonomik faaliyetlerde daha adaletli bir paylaşım yapısını sağlamaya yönelik uygulanan kurumsal yönetim, Türkiye'de faaliyet gösteren yabancı yatırımcıların da yoğun olarak uygulamaya başlamasıyla ekonomik yapı içerisinde yerini almıştır (Kayacan, 2006, s. 29).

İkinci olarak makro ekonomik faktörlerin etkin olduğu nedenlerin bir sonucu olarak ortaya çıkan finansal krizler, önce mikro düzeyde finansal aracılara, daha sonra ekonominin tümüne yayılmıştır. Asya ve Rusya'da yaşanan krizlerden öğrenilen deneyimler ve ABD'de ortaya çıkan şirket skandalları ile başlayan süreç, yatırımcı güvenini tehdit etmeye de başlamıştır. Zayıf kurumsal yönetimden kaynaklı olduğu iddia edilen bu durum, şirketler bazında, hissedarlanı, yöneticileri, kreditörleri ve diğer paydaşları doğrudan etkilerken, ortaya çıkan maliyetler ise ulusal ekonomilerde önemli yükleri de beraberinde getirmiştir (Tuna, 2013, s. 5). Ortaya çıkan küresel bazdaki finansal krizlerin arkasındaki en önemli nedenlerden biri, yukarıda ifade edildiği gibi, işletmelerin kurumsal yönetim faaliyetlerinin yetersizliğinden kaynaklanmaktadır. İşletmeler, küreselleşme ile birlikte hızlı bir rekabet içine girip, bu rekabet şartları içinde büyümeyi sürekli hale getirmek amacı ile uluslararası boyutta bir takım uyum çalışmaları yapmak zorunda olduğu belirtilmelidir. Kurumsal yönetim faaliyeti bu uyum çalşsmalarının en önemlilerindendir. İyi bir kurumsal yönetimin başlangıçta mikro temelde işletme çapında, makro baz da ise ülke genelinde fayda sağlayacağı mutlak bir sonuçtur(Karamustafa vd, 2009, s. 101).

Kurumsal yönetim, bireysel ve toplumsal hedefler ile ekonomik ve sosyal hedefler arasinda denge kurmakla ilgilidir. Kurumsal yönetim çerçevesi, kaynakların verimli kullanımını teşvik eder ve bu 
kaynakların sorumluluğu/yönetiminin eşit şekilde hesap verebilirliğini de teşvik eder. Amaç, bireylerin, şirketlerin ve toplumun çıkarlarının mümkün olduğunca eşit düzeyde uyumlu hale getirmektir. Uluslararası kabul edilen kurumsal yönetim ilkeleri işletmelerin, kurumsal amaçlarına ulaşmasını ve bunun yanı sıra işletmelerin yatırımcı çekmesini de amaçlamaktadır(Iskander ve Chamlaou, 2000, s. 4).

Kurumsal yönetim uygulamaları, işletmelerin hem hissedarlar hem de yatırımcılar başta olmak üzere diğer menfaat sahiplerine en yüksek faydayı sağlayacak biçimde yönetilmesini temel almaktadır. $\mathrm{Bu}$ bağlamda kurumsal yönetim uygulamaları iki temel amaca hizmet etmektedir. Bunlar; (1) menfaat sahiplerine güvenilir bilgi sağlamak, (2) işletmenin piyasa değerini maksimize etmektir (Gör vd., 2016, s. 675).

Kurumsal yönetimin amaçlarına ulaşması ve kurumsal yönetimden beklenen faydanın sağlanabilmesi için kurumsal yönetim sistemi bir takım ilkeleri bünyesinde barındırmaktadır. Cadbury Raporu'na göre; etkin bir şekilde çalsşan kurumsal yönetim için temel ilkeler açıklık, dürüstlük ve hesapverebilirliktir. OECD’ye göre kurumsal yönetimin temel ilkeleri ise; adillik, sorumluluk, şeffaflık ve hesapverebilirliktir (Aracı ve Yüksel, 2016, s. 106).

OECD’nin Kurumsal Yönetim İlkeleri’nin beşinci başlığı Kamuyu Aydınlatma ve Şeffaflık İlkesidir. $\mathrm{Bu}$ başlık altında kamuyu aydınlatma ve şeffaflık; "Kurumsal yönetim çerçevesi sirketin finansal durumu, performansı, ortakllk yapısı ve yönetimi dâhil olmak üzere sirkete iliskin her türlü önemli konuda zamannnda ve doğru açılamalarn yapılmasım sağlamalıdır" şeklinde tanımlanmaktadır. (OECD, G20/OECD Kurumsal Yönetim İlkeleri)

Türkiye Muhasebe ve Finansal Raporlama Standartları'nın temel yapı taşı olan Kavramsal Çerçeve'ye göre(KGK, Finansal Raporlamaya İlişkin Kavramsal Çerçeve), işletmenin ekonomik kaynakları, işletmeye karşı ileri sürülebilen haklar ve bu kaynaklar ile haklarda değişime neden olan işlemler, diğer olaylar ve koşulların etkileri hakkında bilginin finansal raporlarla sağlanmakta olduğu belirtilmektedir. Finansal bilginin kullanıcılara faydalı olabilmesi için ilgili olayları sunması yeterli değildir. Bununla birlikte açıklamayı amaçladığı ekonomik olayları gerçeğe uygun bir şekilde ve zamanında sunması gerektiği belirtilmektedir.

\section{Şeffaflı̆̆1 Arttırmaya Yönelik Mekanizmalar}

İşletmelerin şeffaflı düzeylerinin arttırılmasına yönelik mekanizmalar olarak; bağımsız denetim, muhasebe ve finansal raporlama standartları, iç kontrol ve risk yönetimi, zorunlu kamuyu aydınlatma yükümlülüğü, finansal olmayan raporlama sayllabilmektedir.

\section{Bağımsız Denetim}

Finansal tabloların denetiminde amaç, finansal tabloların bir bütün olarak saptanmış ölçütlerle uyum içinde bulunup bulunmadıklarını araştırmaktır (Güredin, 2014, s. 16). İşletmelerin faaliyet raporlarında halka açıkladıkları muhasebe bilgileri, etkin bir sermaye piyasasının gelişiminde önemli bir role sahiptir. Denetçilerin firmalar tarafindan açıklanan bilgilere etkisinin belli ölçüde o ülkedeki denetçilerin yapısı ve gelişmişlik düzeyi ile denetçilerin denetledikleri firmaları daha ayrıntılı bilgi vermeye teşvik etme ve zorlama yeterliliklerine bağlı olabileceği beklenmektedir (Çürük, 2004, s. 150).

Şeffaflı̆̆ın sağlanabilmesinin en önemli unsuru güçlü bir bilgi açıklama politikasıdır. Bu durum, şirketlerin piyasada devamlı ve tutarlı bir şekilde gözetlenmesi, değerlendirilmesi ve ilgili tarafların bilgilendirilmesiyle sağlanır. Bununla birlikte, hissedarların, sahiplikten doğan haklarını elde etmelerini ve söz konusu haklarını kullanmalarını sağlar. Şeffaflı̆̆ın sağlanamadığı veya yanlış bilgilendirmenin olduğu durumlarda menfaat sahipleri çok büyük zarar göreceklerdir (Sevim ve Şen, 2014, s. 151).

Kurumsal yönetim, finansal raporlama sisteminin izlenmesinde en önemli unsurdur. Teorik olarak kurumsal yönetimin güvenilir bir biçimde var olabilmesi için üç izleme mekanizması bulunmaktadır ki bunlar; bağımsız denetim, iç denetim ve yönetim olarak ifade edilebilir (Abdullah vd., 2008, s. 17). Bu bakımdan bağımsız denetimin en önemli amaçlarından biri, piyasada güven ortamının sağlanmasıdır. $\mathrm{Bu}$ sebeple hazırlanan finansal tabloların denetçiler tarafindan iyi analiz edilmesi gerekmektedir. Ayrıca finansal tablolara güvenilirliğin sağlanması için finansal tablo hazırlama sürecinin de iyi işlemesi gerekmektedir. Bu sorumluluk tamamen işletmenin sorumluluğunda olup, güçlü bir kurumsal yönetim sisteminin oluşturulması ile yerine getirilebilir. Çünkü finansal raporlama süreci, işletmenin bütün birimlerinden etkilenmektedir (Demirkan, 2016, s. 44). 
Finansal raporlar en basit ifadeyle, işletmelerin finansal durumlarını ve faaliyet sonuçlarını ortaya koymak ve gelecekteki nakit akımlarını tahmin etmek amacıyla düzenlenir. Finansal raporların, işletmenin aynası olduğu ve işletmeyle ilgili tarafların işletme hakkında karar almalarını sağladığı temel yapı olduğu belirtilmelidir. Geleneksel olarak da muhasebenin önemi ve yüklendiği görev bu şekilde ortaya konulur (Kalmıs, 2006, s. 140).İ̧sletmenin kurumsal yönetim sistemi, bir bakıma işletmenin ilgililerine sunulan finansal bilgilerin sağlanmasını güven altına alan kurallar topluluğudur. Toplum içinde finansal bilgi üretim sistemini oluşturabilmek için, üç düzeyde önlem alınmalıdır. Finansal bilginin oluşturulmasında üç düzey Şekil-3’teki gibi gösterilmiştir (Aysan, 2007, s. 86).

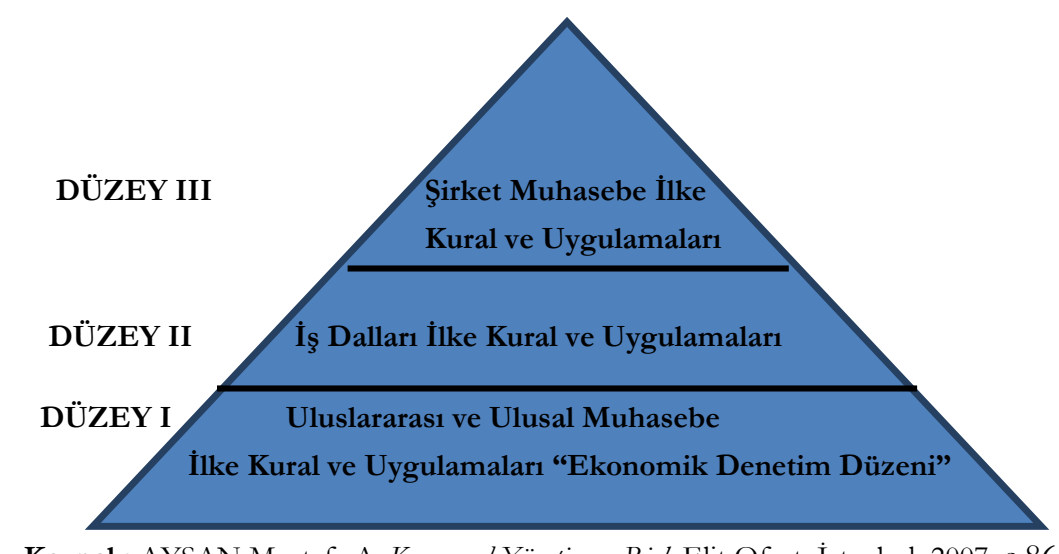

Kaynak: AYSAN Mustafa A.,Kurumsal Yönetim ve Risk,Elit Ofset, İstanbul, 2007, s.86

Şekil1. Muhasebe Uygulamalarnm İyi ve Güvenilir Kurumsal Yönetimdeki Düreyleri

Yukarıdaki şekilde yer alan, tüm düzeydeki kuralların "iyi” ve "güvenilir" olmaları kurumsal yönetim sistemlerinin iyi işlemesi için bir zorunluluktur. Kısaca belirtmek gerekir ise; işletmede kurulabilecek kurumsal yönetim sisteminin amaçlara uygun bir biçimde işletilebilmesi için, dünyada ve ülkelerde "iyi”" muhasebe ilke ve kurallarının geliştirilmesi ve işletmelerin kendi finansal bilgi sistemlerinin de bu kurallara uygun olarak iyileştirilmesini sağlaması oldukça önemlidir (Aysan, 2007, s. 87).

Kurumsal yönetim, işletme dışındaki yatırımcıların, fonlarının yanlış kullanılmasından korunmasını sağlayacak bir ilkeler seti olduğu daha önceki başlıklarda vurgulanmıştır. Kurumsal Yönetimin en önemli fonksiyonunun, finansal raporlama sürecinin kaliteli olmasını sağlamak olduğu ifade edilebilir. Finansal raporlama sürecinin kalitesinin artması, muhasebe kalitesinin de artması sonucunu ortaya çlkaracaktır (Gençoğlu ve Ertan, 2012, s. 18). Bu bakımdan finansal tabloların temel amacına hizmet edecek şekilde finansal bilgi kullanıcılarının ihtiyaç duyduğu bilgileri karşılaması gerekir. İşletmeyle ilgili menfaat sahiplerinin, işletme hakkında doğru, zamanında, güvenilir ve anlaşılabilir bir biçimde bilgilendirilmesi gerekmektedir. Menfaat sahiplerinin, çıkarlarının korunup korunmadığı konusunda şüphelerinden arınabilmeleri için, işletme hakkında sürekli doğru ve dürüst bilgiler sunulması gereklidir. Menfaat sahiplerinin ihtiyaç duyduğu bu bilgilerin çok büyük bir kısmı finansal tablolar yolu ile finansal raporlama kapsamında kamuoyuna sunulmaktadır (Arı, 2009, s. 409).

Yukarıda belirtilen ifadeler, Kavramsal Çerçevede de genel olarak belirtilmektedir. Esasen, Kavramsal Çerçeve, finansal raporlamanın amacını ifade eder. Kavramsal Çerçeve'ye göre; finansal raporlamanın amac1, mevcut ve potansiyel yatırımcılara, borç verenlere ve kredi veren diğer taraflara raporlayan işletmeye kaynak sağlama kararlarını verirken faydalı olacak finansal bilgiyi sağlamaktır. Diğer taraftan Kavramsal Çerçeve'de, genel amaçlı finansal raporların mevcut ve potansiyel yatırımcıların, borç verenlerin ve kredi veren diğer tarafların ihtiyaç duyduğu bütün bilgileri sağlamadıkları belirtilmekte olup, bu duruma ilave olarak, genel amaçlı finansal raporların ihtiyaç duyulan tüm bilgileri sağlamasının da beklenmemesi gerektiği ifade edilmektedir. Bundan dolayı, finansal bilgi kullanıcılarının diğer kaynaklardan elde edilecek bilgileri de göz önünde bulundurması gerektiği belirtilmektedir. Kısaca Finansal Raporlama Standartları şeffaflığı artırmaya yönelik ilke ve kurallar getirmekle birlikte, Kavramsal Çerçevede de belirtildiği gibi; finansal raporlar, büyük ölçüde, kesin açıklamalardan çok tahminlere, yargılara ve yöntemlere dayanır. Kavramsal Çerçeve, bu tahminlerin, yargıların ve yöntemlerin temelini oluşturan esasları belirler.

İşletmelerde şeffaf bir raporlama sisteminin oluşturulması ve işler bir muhasebe sisteminin yerleştirilmesi noktasında, Muhasebe ve Finansal Raporlama Standartlarının sürece çok önemli katkıları olacağı belirtilmelidir. İşletmeler tarafından Muhasebe ve Finansal Raporlama Standartlarının 
uygulanmasıyla birlikte, kaliteli ve karşılaştırılabilirlik niteliklerine sahip raporlama yapılabilecek ve finansal tablolar şeffaf, anlaşılabilir, karşılaştırılabilir ve güvenilir nitelikte olacaktır. Bu sayede faaliyetlerini etkin ve sürekli bir şekilde yürütmek isteyen işletmeler açısından bir zorunluluk haline gelen kurumsallaşma sürecinin önemli koşullarından biri yerine getirilmiş olacak ve işletmelerde etkin bir muhasebe ve finansal raporlama sistemi oluşturulması açısından önemli bir adım atılmış olacaktır (Çelik, 2011, s. 3.).

\section{İç Kontrol ve Risk Yönetimi}

İşletmelerin finansal ve finansal olmayan tüm bilgilerini zamanında, doğru, eksiksiz, anlaşılabilir, yorumlanabilir ve düşük maliyetle kolay erişilebilir bir şekilde kamuya açıklaması şeffaflı̆̆ın gereğidir. Kamuya açılanacak bilgilerden biri de işletmenin gelecekte maruz kalabileceği risklerdir. İşletmenin gelecekte maruz kalabileceği riskler; operasyonel riskler, piyasa riskleri, kredi riskleri, stratejik riskler, faaliyet riskleri, yasal riskler, çevresel riskler, temel iş ile ilgili riskler, denetim riskleri, doğal riskler, finansal raporlama riskleri, uygunluk riski, bilgi riski, ülke riski, itibar riski, kontrol riski, işletme içi ve işletme dış1 riskler, muhasebe içi ve muhasebe dışı riskler, saf ve spekülatif riskler, finansal ve finansal olmayan riskler, sistematik ve sistematik olmayan riskler, iş ortamı ve sanayi riskleri, performans riskleri, personel riskleri, bilgi teknoloji riskleri, politik risk, sosyo-ekonomik riskler, kurumsal yönetimden kaynaklanan riskler, değer zinciri ve destek süreçlerinden kaynaklanan riskler, yetkilendirme riski, finansman riski, likidite riski, kur riski, faiz oranı riski, fiyat riski, sermaye yapısı ve yeterliliği riski, tahribat riski, tahmin riski ve hasar riski olmak üzere birbirinden farklı ve çok fazladır. Söz konusu bu risklerin beklenen ve önemli görülenlerinin işletme yöneticileri, hissedarlar, yatırımcılar, işletmeye kısa ve uzun vadeli kredi sağlayanlar, analistler ve diğer paydaşlar gibi bilgi kullanıcılarına şeffaflı̆ın sağlanması için açıklanması gerekmektedir (Koç ve Özkan, 2016, s. 161).

İşletmelerin özellikle kurumsal yönetim kadrolarına ve denetim komitelerine ciddi yükümlülükler ve yeni raporlama şartları getiren SarbanesOxley Kanunu'nun 302. ve 404. maddeleri tüm işletmelerde risk yönetimini zorunlu kılmaktadır. SarbanesOxley Kanunu; muhasebe gözlem kurulunun kuruluşu ve işleyişi, denetim firmasının bağımsızlığı, şirketin sorumluluğu, mali bilgilerin arttırılması, analiz ve çıkar çatışmaları, komisyon kaynakları ve otoritesi, çalışmalar ve raporlar, kurumsal ve suç unsuru taşıyan suiistimal sorumluluğu, beyaz yakalı suçları ile ilgili cezaların arttrrılması, kurumsal vergi iadeleri ve kurumsal suiistimal ve sorumluluk konuları olarak 11 ana başlıktan oluşmaktadır. Söz konusu kanunun 302 ve 404 numaralı maddeleri çerçevesinde şirketlerin finansal raporlamaları üzerindeki risklerin belirlenmesi, belirlenen risklere ilişkin kontrollerin belgelendirilmesi ve değerlendirilmesi zorunlu olmakla birlikte, kontrollerin etkinliğinden şirket yöneticileri direkt olarak sorumlu tutulmuştur (Güneş ve Teker, 2010, s. 69).

Risk açılama; ilgili tarafları işletmeyi etkileyen ya da gelecekte etkileyebilecek olan herhangi bir firsat, ihtimal, tehlike, zarar, tehdit ya da risklerle ilgili bilgilendirme olarak ifade edilebilir. Risk açıklama, iç kontrolün temel aşamalarından birisi olup, riskleri, eylemleri, önlemleri, yönetimi ve riskle ilgili olayların analizini kapsamaktadır (Koç ve Özkan, 2016, s. 161).

\section{Zorunlu Kamuyu Aydinlatma}

Kamuya açıklanacak bilginin zamanında sunulması gerekmektedir. Bir bilgi ne kadar doğru ve güvenilir olursa olsun, eğer zamanında sunulmamış ise, bilgi kullanıcıları açısından çoğunlukla bir anlam ifade etmeyecektir. Bilgi, finansal bilgi kullanıcılarının alacakları iktisadi kararları etkileme gücünü kaybetmeden önce, karar alma sürecine yardımcı olmalıdır. Bu bakımdan, bilgiyi zamanında açıklama; şeffaflı̆̆ı bir ölçüsü olarak kabul edilmektedir. Sermaye piyasalarının mevcut olduğu bütün ülkelerde halka açık şirketlerde zamanında ve sürekli açıklama yapma gönüllülüğün ötesinde bir zorunluluk haline gelmiştir (Levent, 2015, s. 371).

Şirketlerin zamanında yaptığı kamuyu aydınlatma yatıımcıların, şirketin hisse senetlerini alıp satarken karşılaşacağı zarar riskini düşürmektedir. Bu da şirketin sermaye piyasasında daha çok fon çekmesine sebep olacaktır. Daha çok fon hisse senetlerinin likidite riskini düşürecektir ve dolaylı olarak şirketin finansal performansını etkileyecek sermaye maliyeti de düşecektir (Botoson ve Plumlee, 2002; s. 21-40;Diamond ve Verrecchia, 1991, s. 1325-1359;Brennan ve Tamarowski, 2000, s. 26-37;Leuzve Verrecchia, 2000, s. $91-$ 124).

Acar ve Mortaş tarafından yapılan çalışmada, işletmeler için hesaplanan hesap verebilirlik skorları ile finansal başarı oranları arasında bulunan nedensellik ilişkisi test edilmiştir. Genellikle yüksek hesap 
verebilirlik skoruna sahip işletmeler ile bu işletmelerin verimlilik oranlanı arasında yapılan analizlerde benzerlik göstermiştir. Çalışmanın sonucunda, işletmelerin hesap verebilirlik skoru arttıkça nedensellik bağının daha da arttığı görülmüsstür. İşletmelerin zorunlu kamuya açıklamanın yanı sıra, gönüllü kamuya açıklamayı da artırmalanı gerekmektedir. Böylelikle işletmelerin daha hesap verebilir ve şeffaf olacağı beklenmektedir (Acar ve Mortaş, 2011, s. 85-94).

\section{Finansal Olmayan Raporlama}

İşletmelerin hangi konularda sosyal sorumluluk faaliyetleri yürütecekleri birçok unsura bağlıdır. İşletmenin büyüklügü̆, faaliyet gösterdiği ülkenin gelişmişlik düzeyi, faaliyet gösterdiği sektör, yasal düzenlemeler, rekabet koşulları, tüketicilerin ve toplumun bilinç düzeyi, yöneticilerin bu konuya yaklaşımı gibi faktörler işletmenin sosyal sorumluluk kararlarını belirlemektedir. İşletmeler, sosyal sorumluluk faaliyetlerini eğitim, sağlık, kültür, sanat ve yoksullukla mücadele alanlarını destekleyecek projeler geliştirerek, ekolojik dengeyi bozmayacak ve çevreyi koruyacak yatırımlarda bulunarak gerçekleştirmektedirler (Atakan ve İşçioğlu, 2009, s. 126).

İşletmeler, içinde bulundukları toplumun bir parçası olabilmek için ekonomik amaçları dışında bir takım sosyal ve çevresel amaçlara da sahip olmaları gerektiğinin farkındalığına sahip olmaktadırlar. Böylelikle; paydaş katılımının çerçevesi genişletilerek, işletmeler için "sosyal sorumluluk" kavramı bir yönetim felsefesi olarak ele alınmaya başlanmıştır (Öztürk ve Öktem, 2016, s. 134).

Kurumsal sosyal sorumluluk faaliyetlerinin gün geçtikçe daha da önem kazanması ile birlikte bu faaliyetlerin raporlanması durumu ortaya çıkmıştır. Sosyal sorumluluk faaliyeti yapan işletmeler, yaptıkları faaliyetleri ilgili tüm kamuoyu ile paylaşmak için raporlamaktadırlar. Böylelikle müşteri ve paydaşlar işletme ile ilgili kararlarını daha doğru ve güvenilir bilgiler doğrultusunda verebilmektedirler. Kurumsal sosyal sorumluluk raporları, yıllık faaliyet raporlarında ya da ayrı raporlarda işletmelerin ekonomik, çevresel ve sosyal faaliyetlerinin boyutlarının gösterildiği, işletme içi ve işletme dışı menfaat sahiplerine finansal ve finansal olmayan bilgileri sunan raporlardır (Parlakkaya vd., 2016, s. 885).

Kurumsal yönetim, işletmelerin hem iç hem de diş paydaşlarına karşı sorumluluklarını düzenleyen ilkelerden oluşmakta olup, işletmelerin temel paydaşlarından biri de doğal çevredir. İşletmelerin önemli çevresel sorunların kaynağı olarak görülmesi, bu sorunların çözümü noktasında işletmelerin sorumluluklarını da artırmıştır. Bunun sonucunda işletmeler, çevresel sorumluluklarına ilişkin açıklamalar yapmaya ve çevresel raporlar hazırlamaya başlamışlardır. Çevresel raporlama, finansal, sosyal ve çevresel konulara odaklanan üçlü sorumluluk raporlamasının bir parçasıdır. Söz konusu raporlarda, çevre stratejileri, politikaları, çevresel maliyetler ve çevre yönetim sistemleri konularında yapılan açıklamalar yer almaktadır (Tanç ve Cingöz, 2011, s. 205).

İşletmelerin sadece finansal bilgileri sunan raporlara değil, finansal rapor ilgilileri olarak tanımlanan, paydaşları ilgilendiren, finansal olmayan bilgilerin de raporlanması önemli bir gereklilik haline gelmektedir. Artık işletmeler sadece sattıkları/ürettikleri ürünleri, kârllık oranları veya hisse değerleri ile değil, başta çalışanları olmak üzere, faaliyette bulunduğu topluma ve çevreye karşı ne kadar duyarlı olduğu her zamankinden daha önemli olarak, ön plana çımalarına etki etmektedir. Diğer bir ifade ile, bilinçli toplumlarda, topluma hizmet amacını gözetmeksizin, sadece kâr amacına yönelen işletmelerin başarı şansının daha düşük olduğunun farkına varan işletmelerin, sosyal sorumluluğu amaç olarak benimsemeye başlamaları ile birlikte muhasebe de daha geniş bir bakış açısı ile ele alınmaya başlanmıştır. Çevresel Raporlama Sosyal Sorumluluk Raporlamasının bir alt raporu olmakla birlikte, denetlenmiş veya denetlenmemiş finansal olmayan çevresel bilgilerin finansal raporlara ek olarak veya finansal raporlar ile birlikte yayınlanmasıdır (Yanık ve Türker, 2012, s. 297).

Finansal durumun raporlanmasının ötesinde sosyal sorumluluk uygulamaları ve işletmelerin yaptıkları uygulamalara yönelik raporlama, işletmeler açısından birçok faydayı da beraberinde getirmektedir. $\mathrm{Bu}$ faydalar aşağıdaki gibi sıralanmıştır (Başar ve Başar, 2006, s. 217);

- Menfaat sahipleri ile görüşmelerde sağlam ve güvenilir bir temel oluşturur ve bunlar (özellikle yatırımcılar, devlet..vb) için geçerli ve tutarlı bilgi sağlayarak şirketin şeffaflığını arttırır.

- Uzun vadede pazar payını, müşteri bağlılığını ve marka değerini arttırmaya katkıda bulunur ve bu durum şirketin piyasa değerini arttırır.

- Çevresel ve sosyal riskleri daha iyi izlemek için, yönetim sistemlerinin uygulanmasını teşvik eder ve kolaylaştırır. 
- Çevresel ve sosyal konulardaki işletme değer ve ilkelerini göstermede yardımcı olur.

Sosyal sorumluluk faaliyetlerinin işletmelere sağladığı yararları inceleyen çalışmaların sonuçlarına göre; işletmelerin sosyal sorunların çözümüne yardımcı olmalarının kısa vadede kar getirmese de, uzun vadede satışlarını arttırma, tüketicilerin işletmeye ve ürünlerine yönelik olumlu tutum sergilemeleri, güven, sadakat ve desteklerinin artması, çalışanlarda yüksek düzeyde işe bağlllığın gelişmesi, işletmenin daha güçlü bir imaja kavuşması, marka değerinin artması, ürün farklılaşması yaratma ve itibar kazanma gibi yararları sağladığ1 da belirtilmektedir (Atakan ve İşçioğlu, 2009, s. 126).

\section{Literatür Taraması}

Literatürde kurumsal yönetim notu ile risk veya getiri arasındaki ilişkinin incelendiği çalışmalar mevcuttur (Sakarya, 2011, s. 147-162; Dağlı vd., 2010, s. 18-31; Çarıkçı vd., 2009, s. 51-72; Yenice ve Dölen, 2013, s. 199-213). Sakarya (2011), kurumsal yönetim ile hisse senedi getiri arasında pozitif bir ilişki tespit etmiştir. Yenice ve Dölen (2013) de borsa değerleri ile kurumsal derecelendirme notu arasında anlamlı bir ilişki tespit etmiştir. Dağlı vd.'ne göre kurumsal yönetim endeksinde yer alan işletmelerin yatırımcılarına ek bir gelir sağlamadığı gibi, yatırımcıların riske girmeyerek, risksiz finansal araçlara yatırım yapmaları durumunda daha kazançlı çıkacaklarından dolayı potansiyel kar kaybına neden olduğu sonucuna varmışlardır (Dağlı vd.,2010).

Finansal performans ile kurumsal yönetim arasındaki ilişkinin incelendiği çalışmalarda ise(Çarıkç1 vd., 2009, s. 51-72; Karamustafa vd.,2009, s. 100-119; Çonkar vd., 2011, s. 81-115; Akbar vd., 2016, s. 417429; Büyükşalvarcı vd.,2010, s.119-143) Çarıkçı vd., (2009) ve Akbar vd., 2016 çalışmalarında kurumsal yönetime uyum ile finansal veya kurumsal performans arasında anlamlı bir ilişki olmadığını gözlemlemişlerdir. Buna karşın, Karamustafa vd. (2009), kurumsal yönetim İndeksi'ne girmeden önceki ve sonraki finansal performansı karşılaştırdığında ise anlamlı farklılıklar ortaya çıktı̆̆ını tespit etmiştir. Benzer şekilde Büyükşalvarcı vd. (2010) kurumsal yönetim endeksine dahil olan işletmelerle dahil olmayanların finansal göstergelerinin karşılaştırmış ve anlamlı farklılıklar bulmuştur.

Şeffaflık Kurumsal Yönetim önemli bir bileşeni olmakla birlikte, Beekes ve Brown (2006) kurumsal yönetim kalitesi yüksek şirketlerin daha çok bilgilendirici kamuyu aydınlatma yaptıklarını tespit etmiştir. Esasında kurumsal derecelendirme notu kamuyu aydınlatma ve şeffaflık notunu da kapsamaktadır. Diğer bir ifadeyle şeffaflık düzeyi kurumsal yönetim derecelendirme notunu da etkilemektedir.

Doğan vd. (2015) bankalar üzerinde yaptıkları çalışmada, finansal performans ile mülkiyet yapısının finansal şeffaflık düzeyiyle bir ilişkisinin olmadığını tespit etmiştir.

Sandeep vd. (2002) gelişmekte olan piyasalarda (Brezilya, Polonya, Güney Afrika, Hindistan, Taylan ve Güney Kore) yapmış olduğu çalışmada, Güney Afrika'nın dışındaki piyasalarda Piyasa Değeri/Defter Değeri oranı ile Kamuyu aydınlatma ve şeffaflık puanı arasında pozitif bir ilişki bulmuştur.

Cheung vd.(2010) yaptıkları çalışmanın sonucuna göre, şirketleri piyasa değerleri ile endeksi oluşturulan şirketlerin şeffaflık dereceleri arasında pozitif ve anlamlı bir ilişki vardır. Zorunlu kamuyu aydınlatma ve gönüllü kamuyu aydınlatma yapan şirketler ayrı endekslendiğinde ise, piyasa değeri ile yalnız gönüllü kamuyu aydınlatma endeksi arasında ilişki görülmüştür (Cheung vd., 2010).

Yapılan çalışmanın araştırma sorusunun temelinde ise, finansal performansın şeffaflı̆̆ı etkileyip etkilemediğidir. Diğer bir ifadeyle finansal performansın olumlu yönde olması şeffaflı̆̆ da olumlu yönde etkileyip etkilemediği araştırılmıştır. Bu bağlamda elde edilen verilere TOPSIS ve panel veri analizi yöntemi uygulanarak araştırma sorusunun cevabı aranmıştır.

\section{Yöntem}

Uygulamada, çok kriterli karar verme tekniklerinden TOPSIS Yöntemi ile Yatay (Birim) ve Period (Zaman) boyutlu verilerin analizinde kullanılan Panel Veri Analiz Yöntemi kullanılmıştır.

Çalışmanın veri seti, BIST Kurumsal Yönetim Endeksi (BİST XKURY)'nde işlem gören firmalar esas alınarak oluşturulmuştur. Endekste yer alan 49 firmadan, öncelikle bulundukları endeksle birlikte BIST 100 Endeksinde yer alan firmalar tercih edilmiş, daha sonra bu firmalardan BİST XKURY'nun kuruluş y1lı 2007 y1lından bu yana, kurumsal derecelendirme kuruluşları tarafindan alt başlıkları Kurumsal Yönetim puanları hesaplananlar seçilmiştir. Optimum sayıda veriyi elde etmek adına verilerin kesintisiz olma 
durumuna da dikkat edilerek 2012 ve 2016 yilları arasında (5 yıllık) 23 firma (bankacilık ve mali kurumlar dışında) veri seti için tercih edilmiştir. Aşağıdaki Tablo 1'de veri setini oluşturan firmalar borsadaki kodlamaları ile birlikte sunulmuştur.

Tablo 1. Analize Tabi Firmalar ve Kısaltmaları

\begin{tabular}{|c|c|c|c|}
\hline KOD & FİRMA ADI & KOD & FİRMA ADI \\
\hline AEFES & Anadolu Efes Biraculle ve Malt San. A.Ş. & OTKAR & Otokar Otomotiv ve Savunma Sanayi A.Ș. \\
\hline ARCLK & Arçelik A.Ş. & PETKM & Petkim Petrokimya Holding A.Ş. \\
\hline ASELS & Aselsan Elektronik Sanayi ve Tic. A.Ş: & PRKME & Park Elektrik Ür. Mad. San. ve Tic. A.S . \\
\hline AYGAZ & Aygaz. A.S. & TAVHL & Tav Havalimanlar Holding A.Ş. \\
\hline CCOLA & Coca-Cola İseçek A.Ş. & TOASO & Tofas Türk Otomobil Fabrikası A.Ș. \\
\hline DOAS & Doğus Otomotiv Servis ve Ticaret A.Ş. & TRCAS & Turcas Petrol A.S. \\
\hline DOHOL & Doğan Şirketler Grubu Holding A.Ş. & TTKOM & Türk Telekomünikasyon A.Ş. \\
\hline ENKAI & Enka Inşaat ve Sanayi A.Ş. & TTRAK & Türk Traktör ve Ziraat Makineleri A.Ş. \\
\hline GLYHO & Global Yatorm Holding A.S. & TUPRS & Tüpras-Türkiye Petrol Rafinerileri A.Ş. \\
\hline HURGZ & Hürriyet Gaz: ve Matbaacullk. A.S.S. & VESTL & Vestel Elektronik Sanayi ve Ticaret A.S.S. \\
\hline IHLAS & İhlas Holding A.S. & YAZIC & Yažcular Holding A.S. \\
\hline ISGYO & Iss Gayrimenkul Yaturm Ortakliğ A.Ş. & & \\
\hline
\end{tabular}

\section{TOPSİS Yöntemi}

TOPSIS Yöntemi, işletmelerin performanslarını değerlendirmede ve karşılaştırmada, çoklu finansal oranları dikkate alarak, çok kriterli karar verme problemlerinin çözümünde kullanılmaktadır (Akyüz, 2011, s. 77). Yöntem Chen ve Hwang (1992) tarafindan Hwang ve Yoon'un (1981) çalışmaları referans gösterilerek ortaya konulmuştur. TOPSIS yöntemiesasında çok kriterli karar verme yöntemlerinden biri olup yöntemde, alternatif seçeneklerin belirli kriterler doğrultusunda ve kriterlerin alabileceği maksimum ve minimum değerler arasında ideal duruma göre karşılaştırılması yapılmaktadır (Demirelli 2010, 104).Bu çalışmada TOPSIS yöntemi finansal performans göstergeleri olan finansal oranların standartlaştırılmış tek bir ölçü haline getirilmesi için kullanılmıştır.

Oran yöntemi ile finansal tablolardaki hesap veya hesap gruplanı arasındaki matematiksel ilişkiler kurularak, işletmenin ekonomik ve finansal yapısı ile karlılık, çalışma durumu hakkında bir yargıya ulaşılmaya çalışılmaktadır. TOPSİS hesaplamasında şirketlerin likidite durumunun tespitinde Cari Oran ve Likidite Oranları kullanılmıştır. Şirket karlılığının belirlenmesinde Aktif Karlılık ve Özsermaye Karlılığ1 oranları kullanılmıştır. İşletme büyüme oranlarını analize dahil etmek adına, Aktif Büyüme ve Özsermaye Büyüme oranları kullanılmıştır. Piyasa değerlemesini tespit etmek adına ise, Piyasa Değeri/Defter Değeri oranı ile Piyasa Değeri/Aktifler oranı TOPSİS hesaplamasına dahil edilmiştir. Veri setinde yer alan firmalardan bir kısmının yatırım şirketi olması nedeniyle faaliyet oranları kullanılmamıştır. Ayrıca borçlanma oranlarından kaldıraç oranı, çalışmada oluşturulacak modelde ayıı olarak işletme riskini temsil edecek şekilde bağımsız değissken olarak kullanılmıştır.

TOPSIS hesaplaması için; belirlenen endeksteki firmaların finansal tablolarından alınan bilgilerle finansal oranlar hesaplanmış ve bulunan oranlar 2011, 2012, 2013, 2014 ve 2015 yllları için ilgili y1lın kriterlerini oluşturmuştur. İlk aşamada ilgili yıllar için kriterlere ait karar matrisi oluşturulmuştur.

Verilerin uygulamaya hazır hale getirilmesinde sonra analize konu işletmelerin; kamuyu aydınlatma ve şeffaflık puanlarının, işletmenin finansal performansıyla anlamlı bir ilişki içerisinde olup olmadığı ve etkilenip etkilenmediği araştırılmıştır. Elde edilen veri seti hem birim boyutu ( 23 şirket) hem zaman boyutu (5 yıl) olması nedeniyle panel veri özelliği taşımaktadır. Elde edilen panel verinin analizi için Eviews 8 programı kullanılmıştır.

\section{Panel Veri Analizi}

Panel veri seti, her bir yatay kesitin zaman serisine sahip olduğu veri setidir. Panel veride yatay kesit (birim) için kullanılan $i$, ve zaman serisi için kullan $t$ alt simgesi birlikte kullanılmaktadır. Diğer bir ifadeyle panel veri zaman serisi ve kesitsel olarak iki boyutludur. 
Hausman Testi:Hausman testi, panel veride sabit etkiler ve rassal etkiler modellerinin arasinda tercih yapımında kullanılmaktadır.

Hausman testinde, $\beta_{0}$ sabit etkiler tahmincisi $\beta_{1}$ rassal etkiler tahmincisi olduğunda hipotezler (Çelik vd., 2016, s. 447):

$\mathrm{H}_{0}=$ Her iki tahminci de tutarlı ve $\beta_{1}$ etkindir.

$\mathrm{H}_{1}=\beta_{0}$ tutarlı ancak $\beta_{1}$ tutarlı değildir.

Hausman testi sabit etkiler tahmincisi ile rassal etkiler tahminci arasındaki farkın ölçülmesi ve değerlendirilmesi olarak görülebilir. Hausman testi sonucu, arada fark varsa ve anlamlı ise $\mathrm{H}_{0}$ ' 1 reddederiz. Diğer bir ifadeyle rassal etkiler modelin tutarlı olduğu hipotez reddedilir ve sabit etkiler tahmincisi kullanılır. Aksi durumda ise, düşük seviyedeki değişkenlik rassal etkiler modelinin daha uygun olduğunu söylemektedir (Asteriou ve Hall, 2015).

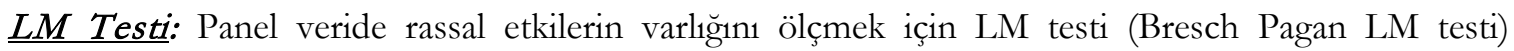
kullanılmaktadır. LM testinde rassal etkilerin varlığının ve yönünün test edilmesinde ortak varyansların sıfıra eşitliği test edilmektedir (Çelik vd., 2016, s. 447). LM testinde havuzlanmıș modelle bir yönlü (birim ya da zaman yönlü) ve iki yönlü rassal etki modelleri arasında uygun modelin tercihinde kullanılmıştır.

F Testi:F testi basit bir yapısal değişikliğin olup olmadığının araştırılmasında kullanılan basit bir Chow testidir. F testi kısıtlanmış regresyon hatalarının karesi ile, kısıtlanmamış regresyon hatalarının karesini içermektedir. Sabit etkilerin birim ve zaman boyutundaki etkisinin varllğını test etmek için kullanılmaktadır. Havuzlanmış model ile bir yönlü (birim ya da zaman yönlü) ve iki yönlü sabit etki modeli arasında uygun modelin seçiminde kullanılmaktadır.

\section{Araştırmanın Analizi ve Bulgular}

Çalışmada finansal performansın ve bunun yanı sıra firma büyüklüğü, firma borçlanma oranının (riskin) ve firma yaşının kamuyu aydınlatma ve şeffaflık puanı üzerindeki etkisi araştırılmaktadır. Finansal performansın (TOPSIS) ortaya çıkması, dönem sonlarında hatta Türkiye örneğinde izleyen dönemin ortalarına doğru yayımlanması durumu ve Kamuyu aydınlatma ve şeffaflık notlarının da bu tarihlere yakın zamanlarda ortaya çıkması nedenleriyle görünürde bir döneme ait TOPSIS puanının, izleyen yılın Kamuyu aydınlatma ve şeffaflık puanıyla ilişki içerisinde olduğu daha makul görülmüştür. Şirketlerin kamuyu aydınlatma ve şeffaflık uygulamaları, işletmelerin finansal performansının etkisi altında kalıp kalmadığ1 araştırmanın ana tezini oluşturmaktadır. Bunun yanı sıra firma büyüklüğü, firma borçlanma oranı ve firma yaşı literatürden hareketle analize dahil edilmiştir.

Söz konusu değişkenlere ilişkin oluşturulan araştırmanın soruları aşağıdaki gibidir:

S1: Finansal performansin (TOPSİS) kamuyu aydinlatma ve seffaflk uygulamalar üzerinde etkisi var midir?

S2: Şirket büyüklï̈ünün (SIZE) kamuyu aydnlatma ve seffaflk uygulamalar üzerinde etkisi var mudir?

S3: Borçlanma oranmm (RISK) kamuyu aydinlatma ve seffaflhe uygulamalar üzerinde etkisi var mıdir?

S4: Şirket yaşınn (AGE) kamuyu aydinlatma ve seffaflı. uygulamalar üzerinde etkisi var muder?

Araştırma sorularında yer alan bağımsız değişkenlerin tamamının dahil edildiği Araşstrma Modelise:

$$
\mathrm{KASN}_{i, t}=a+\beta_{1} \text { TOPSIS }_{i t-1}+\beta_{2} \text { SIZE }_{i t}+\beta_{3} \text { RISK }_{i t}+\beta_{4} A G E_{i t}+{ }_{i} \varepsilon_{i}
$$

Değişkenlere ilişkin açıklamalar ve veri kaynakları Tablo-2'de sunulmuştur. KASN (kamuyu aydınlatma ve şeffaflık notu) bağımlı değişkeni, şirketlerin kurumsal internet sitelerinden elde edilen yılllık faaliyet raporlarından ve derecelendirme şirketlerinin web sitelerinden toplanmıştır. TOPSIS bağımsız değişkeni ise, örneklemde yer alan 23 şirketin sekiz adet finansal oranlarından hesaplanmıştır. TOPSİS puanı modelde finansal performansı temsil etmektedir. Diğer bağımsız değişken SIZE ise, şirket büyüklüğünü temsilen örneklemde yer alan şirketlerin toplam varlıklarının doğal logaritması alınarak elde edilmiştir. Bağımsız değişkendeki değerlerin logaritmasının alınması, verideki asimetrik sorunu azaltmak içindir (Devalle vd., 2016, s. 18). Bağımsız değişken olarak alınan RISK, işletmenin riskini temsilen borçlanma oranı (Toplam Borç/Toplam varlıklar) kabul edilmiştir. Diğer bağımsız değişken AGE ise, şirketin yaşını göstermektedir. 
Tablo 2. Değiskeenlerin Açılaması

\begin{tabular}{|c|c|c|}
\hline Değiskenin $A d 1$ & Değişkenin Açıklaması & Verinin Kaynağı \\
\hline$K A S N$ & Kamuyu aydınlatma ve şeffaflık notu & $\begin{array}{l}\text { Yıllık Faaliyet Raporları, } \\
\text { Şirketlerin kurumsal internet siteleri, } \\
\text { Derecelendirme Şirketlerinin İnternet Siteleri }\end{array}$ \\
\hline TOPSIS & $\begin{array}{l}8 \text { adet }^{4} \text { finansal oran kullanilarak hesaplanmış } \\
\text { finansal performansı temsilen TOPSIS puanı. }\end{array}$ & $\begin{array}{l}\text { Yillık Finansal Tablolar, Kamuyu Aydınlatma } \\
\text { Platformu (www.kap.gov.tr) }\end{array}$ \\
\hline$S I Z E$ & $\begin{array}{l}\text { Şirket büyüklüğü, şirketin toplam varlıklarının } \\
\text { doğal logaritması alınarak hesaplanmıştır. }\end{array}$ & $\begin{array}{l}\text { Yillık Finansal Tablolar, Kamuyu Aydinlatma } \\
\text { Platformu (www.kap.gov.tr) }\end{array}$ \\
\hline RISK & $\begin{array}{l}\text { Şirketin borçlanma düzeyi } \\
\text { (Toplam Borçlar / Toplam Varlıklar) }\end{array}$ & $\begin{array}{l}\text { Yillı Finansal Tablolar, Kamuyu Aydınlatma } \\
\text { Platformu ( } \underline{w w w . k a p . g o v . t r})\end{array}$ \\
\hline$A G E$ & Şirketin Yaş1 & $\begin{array}{l}\text { Sirketlerin kurumsal internet siteleri, } \\
\text { www.wikipedia.org }\end{array}$ \\
\hline
\end{tabular}

Tahmin edilecek modeldeki değişkenlere ait tanımlayıcı istatistikler aşağıda yer alan Tablo-3'de sunulmuştur.

Tablo 3. Tanmlaycc Istatistikler

\begin{tabular}{llllll}
\hline & KASN & TOPSIS & SIZE & RISK & AGE \\
\hline Mean & 9.370470 & 0.388477 & 22.15057 & 53.39922 & 43.17391 \\
Median & 9.362000 & 0.398155 & 22.12970 & 55.86000 & 40.00000 \\
Maximum & 9.947000 & 0.681243 & 23.97263 & 84.72000 & 130.0000 \\
Minimum & 8.290000 & 0.043156 & 19.99781 & 8.400000 & 8.000000 \\
Std. Dev. & 0.344210 & 0.137135 & 1.028565 & 18.94310 & 25.83458 \\
& & & & & 115 \\
$N$ & 115 & 115 & 115 & & \\
\hline
\end{tabular}

Değişkenler arasında ikili korelasyonlarının ve yönlerinin tespiti için, korelasyon analizi yapılmış ve aşağıda yer alan Tablo-4'da gösterilmiştir. KASN ile TOPSIS arasında pozitif yönlü, KASN ile SIZE arasında pozitif yönlü, KASN ile RISK arasında negatif yönlü ve KASN ile AGE arasında ise pozitif yönlü ilişki olduğu görülmektedir.

Tablo 4. Korelasyon Matrisi

\begin{tabular}{lrrrrr}
\hline & I & II & III & IV & V \\
\hline I KASN & 1 & & & & \\
II TOPSIS & 0.3348 & 1 & & & \\
III SIZE & 0.3521 & 0.0291 & 1 & 1 & \\
IV RISK & -0.0977 & -0.1496 & 0.3413 & -0.0802 & 1 \\
V AGE & 0.1640 & 0.0811 & -0.0151 & \\
\hline
\end{tabular}

Literatürde finansal performans ile şeffaflık arasında hem pozitif hem de negatif ilişki tespit eden çalısmalar (Sandeep vd., 2002, s. 325-337; Cheung vd., 2010, s. 325-337) olmakla birlikte, anlamlı bir ilişsi olmadığı sonucuna ulaşan çalıssmalarda mevcuttur (Doğan vd., 2015, s. 305-330). Bu çalışmada ise şeffaflık

${ }^{4}$ Aktif Büyüme, Özsermaye Büyümesi, Piyasa Değeri/Defter Değeri, Piyasa Değeri/Aktifler, Aktif Karlılık, Özsermaye Karlıllı̆̆, Cari Oran ve Likit Oran. 
ve finansal performans arasında Tablo - 5'da görüldüğü üzere anlamlı ve pozitif yönlü bir ilişki olduğu tespit edilmiştir.

Literatürdeki çalışmalara göre firma büyüklüğü ile firmaların kamuyu aydınlatmaları arasında pozitif yönlü anlaml ilişki vardır (Liu ve Anbumozhia, 2009, s. 593-600; Lourenço ve Branco, 2013, s. 134-141; Artiach vd., 2010, s.31-51). Bu çalışmada ise benzer şekilde pozitif yönlü bir ilişki olduğu yine Tablo 5 'da görülmektedir.

Diğer değişken olan firma riski (kaldıraç) ile kamuyu aydınlatma ve şeffaflık arasında literatürdeki bulgulara göre negatif yönlü bir ilişki vardır (Liu ve Anbumozhia, 2009, s. 593-600; Lourenço ve Branco, 2013, s. 134-141; Artiach vd., 2010, s.31-51). Yapılan analizlerde, ulaşılan sonuca göre benzer yönlü fakat çok güçlü olmayan bir ilişki olduğu tespit edilmiş ve Tablo 5’te gösterilmiştir.

Tablo 5. Model Tahminleri Sonuclar

\begin{tabular}{|c|c|c|c|c|c|}
\hline \multicolumn{6}{|c|}{ Bağımlı Değişken: $K A S N$} \\
\hline \multirow[t]{2}{*}{ Bağımsız Değişkenler } & \multicolumn{5}{|c|}{ Regresyon Modelleri } \\
\hline & 1 & 2 & 3 & 4 & 5 \\
\hline Sabit (Constant) & $\begin{array}{c}6.3758^{* * *} \\
(0.6515)\end{array}$ & $\begin{array}{c}6.2915^{* * *} \\
(0.6430)\end{array}$ & $\begin{array}{c}6.5138^{* * *} \\
(0.6188)\end{array}$ & $\begin{array}{c}6.1663^{* * *} \\
(0.6149)\end{array}$ & $\begin{array}{c}6.2353^{* * *} \\
(0.6171)\end{array}$ \\
\hline TOPSIS & & & $\begin{array}{c}0.8152^{* * *} \\
(0.2083)\end{array}$ & $\begin{array}{c}0.7144^{* * *} \\
(0.2056)\end{array}$ & $\begin{array}{c}0.7377^{* * *} \\
(0.2064)\end{array}$ \\
\hline SIZE & $\begin{array}{c}0.1460^{* * *} \\
(0.0305)\end{array}$ & $\begin{array}{c}0.1453^{* * *} \\
(0.0300)\end{array}$ & $\begin{array}{c}0.1147^{* * *} \\
(0.0278)\end{array}$ & $\begin{array}{c}0.1368 \\
(0.0288)\end{array}$ & $\begin{array}{c}0.1371 \\
(0.0289)\end{array}$ \\
\hline RISK & $\begin{array}{c}-0.0044^{* * *} \\
(0.0016)\end{array}$ & $\begin{array}{l}-0.0042^{* *} \\
(0.0016)\end{array}$ & & $\begin{array}{c}-0.0033^{* *} \\
(0.0016)\end{array}$ & $\begin{array}{c}-0.0035^{* *} \\
(0.0016)\end{array}$ \\
\hline$A G E$ & & $\begin{array}{c}0.0020 \\
(0.0011)\end{array}$ & & $\begin{array}{c}0.0018 \\
(0.0011)\end{array}$ & \\
\hline Hausman-ist & 5.6248 & 5.3917 & 5.0042 & 5.2515 & 5.3947 \\
\hline Uygun Model & Rassal Etkiler & Rassal Etkiler & Rassal Etkiler & Rassal Etkiler & Rassal Etkiler \\
\hline LM Çift Yön & $6.1919^{* * *}$ & $6.0383^{* * *}$ & $5.3134^{* * *}$ & $5.1123^{* * *}$ & $5.2260^{* * *}$ \\
\hline & & Modele İlişkin I & stikler & & \\
\hline $\mathrm{R}^{2}$ & 0.1778 & 0.2006 & 0.2294 & 0.2788 & 0.2615 \\
\hline Düzeltilmiş $\mathrm{R}^{2}$ & 0.1630 & 0.1790 & 0.2156 & 0.2526 & 0.2416 \\
\hline F İstatistiği & $12.1039^{* * *}$ & $9.2849^{* * *}$ & $16.6682^{* * *}$ & $10.6328^{* * *}$ & $13.1042^{* * *}$ \\
\hline Firma Sayıs1 & 23 & 23 & 23 & 23 & 23 \\
\hline Gözlem Sayısı & 115 & 115 & 115 & 115 & 115 \\
\hline
\end{tabular}

Not: Tabloda yer alan $*, * *$ ve*** işaretleri test istatistiğinin $\% 10, \% 5$ ve $\% 1$ önem düzeyinde anlamlı olduğunu göstermektedir.

Parantez içindeki değerler ilgili katsayıların standart hatalarıdır.

\section{Tartışma, Sonuç ve Öneriler}

Finansal performans, firma büyüklüğü, firma borçlanma oranı ve firma yaşının kamuyu aydınlatma ve şeffaflık puanı (KASN) üzerindeki etkisini araştırmak için 5 farklı model tahmin edilmiştir. Modellerde sabit ve rassal etkilerin varllğını ve yönlerini belirlemek için Hausman Testi, LM Testi ve F Testi yapılmıştır. Testler sonucunda rassal etkiler modelinin (Hausman Testi ile) daha uygun olduğu ve rassal etkilerin çift yönlü olduğu sonucuna (LM Testi) ulaşılmıstır. Elde edilen bulgular yukarıdaki yer alan Tablo 5 't e gösterilmektedir.

1. Modelde, firma büyüklüğü ve borçlanma oranı bağımsız değişken olarak alınmıştır. Tahmin edilen model istatistiksel olarak anlamlı (Tablo 5'te yer alan F istatistiği) ve KASN bağımlı değişkeninin \% 16'sını açıklamaktadır. 
2. Modelde ise, firma büyüklüğü, borçlanma oranı ve firma yaşı bağımsız değissken olarak alındığında, model anlamlı olarak çalışmakta ve model KASN bağımlı değişkenini $\% 17$ oranında açıklamaktadır. Ancak modelde firma yaşı (AGE) bağımsız değişkeni istatistiksel olarak anlamlı çıkmamıştır.

3. Modelde, finansal performans ve firma büyüklüğü bağımsız değişken olarak alınmıştır. Bu model de istatistiksel olarak anlamlı olarak sonuçlanmış ve modelin çalıştığı belirlenmiştir. Bulunan sonuca göre; model KASN bağımlı değişkenini \% 22 oranında açıklamaktadır.

4. Modelde, finansal performans, firma büyüklüğü, borçlanma oranı ve firma yaşı bağımsız değişken olarak modele dâhil edildiğinde, söz konusu model beklendiği gibi çalışmaktadır ve söz konusu bağımsız değişkenlerin, KASN bağımlı değişkenini \% 25 açılamaktadır. Ancak bu modelde bağımsız değişkenlerden firma yaşının (AGE) anlamlı bir etkisi olmadığı görülmektedir. Bununla birlikte Tablo 5’te de görüldüğü gibi, kurulan modellerin ikisinde (2. ve 4. Model) firma yaş1 istatistiksel olarak anlamlı çıkmamıştır.

5. Modelde ise, AGE değişkeni çıkarıldığında diğer bağımsız değisskenlerin yer aldığ1 4. Modele göre daha uygun olarak çalışmakta ve istatistiksel olarak anlaml olduğu görülmektedir (F istatistiği 10,6328 iken 13,1042 olmakta). Bu modelin ise, KASN değişkenini \% 24 oranında açıkladığ1 görülmektedir.

Hiç bir ülke, şirket, organizasyon ya da birey doğal olarak şeffaf değildir. Güvenlik ve kalite gibi, şeffaflık da bir süreçtir, bir hedef değildir. Şeffaflık hemen olup biten bir şey de değildir. Şeffaflık bilinçli bir sorumluluğun, uzun dönem hedeflerin, dikkatle yapılmış politikaların, istikrarla uygulanmasının sonucu ortaya çıkabilmektedir. Bu süreçte şeffaflık, yeni piyasa gereksinimlerine ve gelişen örgütsel yeteneklere cevap olarak sürekli güncelleme istemektedir (Oliver, 2004, s. 33-60). Şeffaflı̆̆ın bu özellikleri ile beraber, şeffaflığı etkileyen veya tetikleyen etkenler de elbette söz konusudur. Her bir organizasyon için değişkenlik gösterebilecek bu etkenler, işletmeler bazında ele alınacak olunursa; işletmelerin finansal performanslarının şeffaflık üzerinde muhtemel etkiye sahip olduğu düşünülebilir ve bu sav, çalsşmanın konusunu oluşturmaktadır.

Çalışmada, örnek kütle oluşturularak işletmelerin finansal performansları ile şeffaflık ve kamuyu aydınlatma seviyeleri arasındaki ilişki ortaya konmaya çalışılmıştır. BIST XKURY Endeksi örnek kütlenin kaynağı olarak kabul edilmiştir. Bazı kısıtlar nedeniyle, bu işletmelerden elemeler yapılarak nihai olarak verilerin de kesintisiz olması dikkate alındığında, beş yıllık bir süreçte 23 işletme yani toplamda 115 gözlem örnek kütleye dâhil edilmiştir.

İşletmelerin finansal performanslarını temsil etmesi adına, işletmelere ait finansal rasyolar elde edilerek; çok amaçlı karar verme yöntemlerinden TOPSİS yöntemiyle, her bir işletme için TOPSİS puanı oluşturulmuştur. Hesaplanan TOPSIS puanlarının, bu çalışma için ilgili işletmelerin finansal performansını temsil ettiği kabul edilmiştir. Diğer taraftan şeffaflık ve kamuyu aydınlatma uygulama seviyelerini temsilen, söz konusu işletmelerin faaliyet raporlarında da sunmuş oldukları Kamuyu Aydınlatma ve Şeffaflık Notları dikkate alınmıştır.

Ayrıca çalışmada işletmelerin kamuyu aydınlatma ve şeffaflık uygulamaları üzerinde firma büyüklükleri, firma borçlanma oranları ve firma yaşlarının etkisi araştırılmıştır. Bu bakımdan çalışmanın uygulamasının test edilmesi için geliştirilen modelin bağımsız değişkenleri olarak; TOPSIS puanlar, işletme büyükliükleri, işletme borçlanma oran (işlletme riski) ve işletme yaşları dikkate alınmıştır.

Bir döneme ait finansal performansın (TOPSIS) hesaplanabilmesi Türkiye örneğinde, izleyen dönemin ortalarına doğru mümkün olmakta ve Kamuyu aydınlatma ve şeffaflık notlarının da bu tarihlere yakın zamanlarda ortaya çıkması nedenleriyle, görünürde bir döneme ait TOPSIS puanının, izleyen yılın Kamuyu aydınlatma ve şeffaflık puanıyla ilişki içerisinde olduğu daha makul görülmüştür. Benzer yaklaşım diğer bağımsız değişkenler içinde uygulanmıştır.

Yapılan analizler sonucunda, işletmelerin kamuyu aydınlatma ve şeffaflık uygulamaları, işletmelerin finansal performansından etkilenmektedir. Diğer bir ifadeyle, işletmelerin finansal performansının artması kamuyu aydınlatma ve şeffaflık uygulama seviyesini de pozitif yönde etkilemektedir. Finansal performansla beraber analize dahil edilen firma büyüklüğü ve firma borçlanma oranının da, kamuyu aydınlatma ve şeffaflık uygulamaları üzerinde etkisi olduğu gözlemlenmiştir. Firma büyüklügünün pozitif yönlü etkisi olduğu, firma borçlanma oranının ise negatif yönlü etkisi olduğu görülmüştür. Ayrıca firma yaşı, model tahminlerinde modellere dahil edilmiş ancak, kamuyu aydınlatma ve şeffaflık uygulamaları üzerinde anlamlı bir etkiye sahip olmadığ1 görülmüştür. 
Araştırmada sorularının cevaplanabilmesi için yapılan analizler sonucunda:

- İşletmelerin finansal performanslarının, kamuyu aydınlatma ve şeffaflık uygulama seviyeleri üzerinde pozitif yönlü anlamlı etkisi vardır. Finansal performansın artması ile kamuyu aydınlatma ve şeffaflık uygulama seviyesinde bir artma söz konusudur.

- İşletme büyüklüklerinin, işletmelerin kamuyu aydınlatma ve şeffaflık uygulamaları üzerinde pozitif yönlü anlamlı etkisi vardır. İşletmelerin büyüklüklerinin artmasıyla kamuyu aydınlatma ve şeffaflık uygulaması da artmaktadır.

- İşletme borçlanma oranının, kamuyu aydınlatma ve şeffaflık uygulamaları üzerinde negatif yönlü anlamlı bir etkisi olduğu gözlemlenmiştir. İşletme borçlanma oranı, diğer bir ifadeyle, şirket riski arttığında, işletmenin kamuyu aydınlatma ve şeffaflık uygulama seviyelerinde düşme görülmektedir.

- İşletme yaşının, işletmenin kamuyu aydınlatma ve şeffaflık uygulamaları arasında ancak anlamlı olmayan bir etki görülmektedir. İşletme kuruluş yllı dikkate alınarak hesaplanan işletme yaşının, işletmenin kamuyu aydınlatma ve şeffaflık uygulama seviyelerini etkilemediği görülmektedir.

Sonuç olarak; işletmelerin finansal performansının, büyüklüklerinin, borçlanma oranlarının, işletmelerin kamuyu aydınlatma ve şeffaflık uygulamalarının belirleyicileri arasında bulunduğu yapılan analizler sonucunda tespit edilmiştir.

Yine yapılan analizlerden elde edilen sonuçlara göre, işletmenin yaşı ile şeffaflık ve kamuyu aydınlatma seviyesinin birbirlerini etkilemediği görülmektedir. Kısaca, işletme yaşına göre, şeffaf ya da şeffaf değil gibi çıkarım yapılamamaktadır. Esasen, ister genç bir işletme olsun ister uzun süredir faaliyetine devam eden bir işletme olsun önemli olan başarısını sağlamak ve başarıyı sürdürebilir kılma için şeffaflık ve kamuyu aydınlatma ilkesini benimsemiş olması yani kurumsallaşmış olması gerekmektedir.

Çalışma; işletme ile ilişki içindeki gruplara özellikle de yatırımcılara, işletmelerin şeffaflık ve kamuyu aydınlatma puanını yorumlarken, finansal performans ve borçlanma oranının (işletme riskinin), bu puanının belirleyicileri arasında olduğunu ortaya koyarak bir rehberlik sağlaması yönünden önem arz etmektedir.

\section{Kaynakça}

Abay, R. (2013). Denetim yapısı ile finansal şeffaflık üzerine bir inceleme. Çukurova Üniversitesi Sosyal Bilimler Enstitüsü Dergisi, 22(2), 165-174.

Abdullah, W. Z., Ismail, W. S. ve Jamaluddin, N. (2008). The impact of board composition, ownership and CEO duality on audit quality: The Malaysian evidence. Malaysian Accounting Review, 7(2), 17-28.

Acar, D. ve Mortaș, M. (2011). İșletmelerin hesap verebilirlikleri ile performans arasındaki ilișki: İMKB-30 endeksinde yer alan işletmeler üzerine bir araştırma. Karamanoğlu Mehmetbey Üniversitesi Sosyal ve Ekonomike Arastirmalar Dergisi, 13(21), 85-94.

Akbar, S., Poletti-Hughes, J., El-Faitouri, R. ve Ali-Shah, S. Z. (2016). More on the relationship between corporate governance and firm performance in the UK: evidence from the application of generalized method of moments estimation. Research in International Business and Finance, 38, 417-429.

Akyüz, Y., Bozdoğan, T. ve Hantekin, E. (2011). TOPSIS yöntemiyle finansal performansın değerlendirilmesi ve bir uygulama. Afyon Kocatepe Üniversitesi İIBF Dergisi, 13(1), 73-92.

Aracı, H. ve Yüksel, F. (2016). Şeffaflık ve hesap verebilirliğin sağlanmasında sürdürebilirlik raporları: BIST sürdürebilirlik endeksindeki şirketlerin sürdürebilirlik raporlarının incelenmesi. Mubasebe Bilim Dünyası Dergisi, 18(Özel Say1 1), 103-131.

Arı, M. (2009). Finansal raporlama skandalları ve mali tabloların güvenilirliği. Dumlupınar Üniversitesi Sosyal Bilimler Dergisi, 23, 409-429.

Arsoy, A. P. (2008). Kurumsal şeffaflık ve muhasebe standartları. Afyon Kocatepe Üniversitesi İIBF Dergisi, 10(2), 17-35.

Artiach, T., Lee, D., Nelson, D. ve Walker, J. (2010). The determinants of corporate sustainability performance. Accounting \& Finance, 50(1), 31-51.

Asteriou, D. ve Hall, S. G. (2015). Applied Econometrics. USA: Palgrave Macmillan.

Atakan, M. G. S. ve İşçioğlu, T. E. (2009). Türk tüketicilerinin bakış açısıyla işletmelerin kurumsal sosyal sorumluluk faaliyetleri. Marmara Üniversitesi Öneri Dergisi, 8(32), 125-133.

Aysan, M. A. (2007). Kurumsal yönetim ve risk. İstanbul: Elit Ofset. 
Başar, A. B. ve Başar, M. (2006). Sosyal sorumluluk raporlaması ve Türkiye'deki durumu. Anadolu Üniversitesi Sosyal Bilimler Dergisi, 6(2), 213-230.

Beekes, W. ve Brown, P. R. (2006). Do better governed Australian firms make more informative disclosure? Journal of Business Finance \& Accounting, 33(3-4), 422-450.

Botosan, C. A. ve Plumlee, M. A. (2002). A re-examination of disclosure level and the expected cost of equity capital. Journal of Accounting Research, 40(1), 21-40.

Brennan, M. J. ve Tamarowski, C. (2000). Investor relations, liquidity, and stock prices. Journal of Applied Corporate Finance, 12(4), 26-37.

Büyükşalvarc1, A. ve Abdioğlu, H. (2010). IMKB kurumsal yönetim endeksi’nde işlem göre şirketlerin finansal ve finansal olmayan belirleyicileri: İMKB imalat sektörü üzerine bir uygulama. Mubasebe Bilim Dünyası Dergisi, 12(3), 119-143.

Cheung, Y. L., Jiang, P. ve Tan, W. (2010). A transparency disclosure index measuring disclosures Chinese listed companies. Journal of Accounting and Public Policy, 29(3), 259-280.

Çarıkçı, H. İ., Kalaycı, Ş. ve Gök, İ. Y. (2009). Kurumsal yönetim-şirket performansı ilişkisi: İMKB kurumsal yönetim endeksi üzerine ampirik bir çalışma. Alanya Issletme Fakültesi Dergisi, 1(1), 51-72.

Çelik, O. (2011). Kurumsallaşmanın sağlanmasında TMSK'nın rolü. 10. Muhasebe Denetim Semposyumu 5-9 Ekim, http://archive.ismmmo.org.tr/docs/Sempozyum/10/TR/ORHANCelik.pdf 14.01.2017, 1-6.

Çelik, S., Zeytinoğlu, E. ve Akarım, Y. D. (2016). Kurumsal sosyal sorumluluk ve finansal performans arasındaki ilişki: borsa İstanbul üzerine bir uygulama. Muhasebe Bilim Dünyası Dergisi, 18(Özel Say1 1), 439-453.

Çonkar, M. K., Elitaş, C. ve Atar, G. (2011). İMKB kurumsal yönetim endeksi'ndeki (XKURY) firmaların finansal performanslarının TOPSIS yöntemi ile ölçümü ve kurumsal yönetim notu ile analizi, İktisat Fakültesi Mecmuası, 61(1), 81-115.

Çürük, T. (2004). Bağımsız dış denetimin muhasebe şeffaflığına etkisi üzerine uygulamalı bir çalışma: Türkiye örneği. ODTÜ Gelisme Dergisi, 31, 149-165.

Dağlı, H., Ayaydın, H. ve Eyyüboğlu, K. (2010). Kurumsal yönetim endeksi performans değerlendirmesi: Türkiye örneği. Mubasebe ve Finansman Dergisi, 48, 18-31.

Demireli, E. (2010). TOPSIS çok kriterli karar verme sistemi: Türkiye'deki kamu bankaları üzerine bir uygulama. Girişimcilik ve Kalkınma Dergisi, 5 (1), 101-112.

Demirkan, A. (2016). Bağımsız denetim kuruluşlarında şeffaflık raporları - uluslararası uygulamalar ve Türkiye. Mubasebe ve Denetim Dünyası, 1(1), 43-54.

Devalle, A., Rizzato, F. ve Busso, D. (2016). Disclosure indexes and compliance with mandatory disclosure - The case of intangible assets in the Italian market. Advances in Accounting, 35, 8-25.

Diamond, D. W. ve Verrecchia, R. E. (1991). Disclosure, liquidity, and the cost of capital. The Journal of Finance, 46(4), 1325-1359.

Doğan, M., Elitaş, B. L. ve Mecek, G. (2015). Bankaların şeffaflık düzeyleri ile finansal performans göstergeleri arasındaki ilişkinin test edilmesi. Muhasebe Bilim Dünyası Dergisi, 17(2), 305-330.

Gençoğlu, Ü. G. ve Ertan, Y. (2012). Muhasebe kalitesini etkileyen faktörler ve Türkiye'deki durumu. Mubasebe ve Finansman Dergisi, 53, 1-24.

Gör, Y., Terzi, S. ve Şen, İ. K. (2016). Şeffaflık açısından kurumsal yönetim uygulamalarının finansal raporlamanın süresi üzerine etkisi: Borsa İstanbul örneği. Muhasebe Bilim Dünyası Dergisi, 18 (Özel Say1 I), 673-705.

Güler, E. (2011). Faaliyet alanlarının kapsamına göre ayrılmış bağımsız denetim firmalarının uluslararası denetim standartlarına (ISA's) ve kurumsal yönetim uygulamaları hakkındaki görüşlerine ilişkin bir araştırma. Selçuk Üniversitesi İ̈BF Sosyal ve Ekonomike Arasttrmalar Dergisi, 21, 95-117.

Güneş, Ş. ve Teker, S. (2010). Türk enerji sektöründe kurumsal risk yönetimi farkındalığı. Doğus Üniversitesi Dergisi, 11(1), 64-76.

Güredin, E. (2014). Denetim ve güvence bizmetleri. İstanbul: Türkmen Kitabevi.

Iskander, M. R. ve Chamlaou, N. (2000). Corporate Governance: A Framework for Implementation. The International Bank for Reconstruction and Development/The World Bank, Washington USA.

Kalmış, H. (2006). Geleneksel finansal raporlama, muhasebeden beklentiler ve sorunlar. Çanakkale Onsekiz Mart Üniversitesi Girişimcilike ve Kalk.nma Dergisi, 1(2), 1-5.

Karamustafa, O., Varıc1, İ. ve Er, B. (2009). Kurumsal yönetim ve firma performansi: İMKB kurumsal yönetim endeksi kapsamındaki firmalar üzerinde bir uygulama. Kocaeli Üniversitesi Sosyal Bilimler Enstitüsü Dergisi, 17, 100119.

Kayacan, M. (2006). Küreselleşen Dünyamızda Yeni Şirket Gündemi: Kurumsal Yönetim. İstanbul: Türkiye Etik Değerler Yayın Merkezi Vakfı (TEDMER) Yayını.

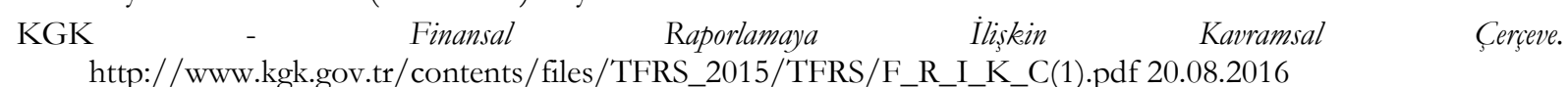




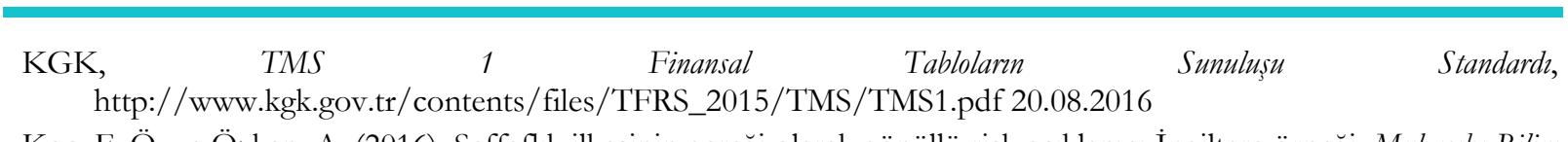

Koç, F. Ö. ve Özkan, A. (2016). Şeffaflık ilkesinin gereği olarak gönüllü risk açıklama: İngiltere örneği. Muhasebe Bilim Dünyası Dergisi, 18 (Özel Sayı: I), 157-175.

Leuz, C. ve Verrecchia, R. E. (2000). The economic consequences of increased disclosure (digest summary). Journal of Accounting Research, 38, 91-124.

Levent, C. E. (2015). Küresel finans krizi sonrasında sermaye piyasalarında şeffafllğın arttırılması: Türkiye örneği. International Conference on Eurasian Economies, 370-380.

Liu, X. ve Anbumozhi, V. (2009). Determinant factors of corporate environmental information disclosure: An empirical study of chinese listed companies. Journal of Cleaner Production, 17(6), 593-600.

Lourenço, I. C. ve Branco, M. C. (2013). Determinants of corporate sustainability performance in emerging markets: The Brazilian case. Journal of Cleaner Production, 57(15), 134-141.

Mortaş, M. (2011). Işsletmelerin hesap verebilirliklerinin performanslarna etkisi: IMKB - 30 endeksinde bir araștırma (Doktora Tezi). Süleyman Demirel Üniversitesi Sosyal Bilimler Enstitüsü, Isparta.

OECD, G20/OECD (2015). Kurumsal Yönetim İlkeleri, OECD’nin G20 Bakanlar ve Merkez. Bankası Başkanlarna Raporu, Eylül 2015, https://www.oecd.org/daf/ca/Corporate-Governance-Principles-TUR.pdf 01.10.2106

OECD (2015). Kurumsal Yönetim Illkeleri, $\quad$ Eylül http://www.tkyd.org/files/images/content/faaliyet_alanlari/haberler/Corporate-Governance-PrinciplesTUR.pdf 15.08.2016

Oliver, R. (2004). What is transparency? McGraw Hill Professional.

Öztürk, E. ve Öktem, B. (2016). Sosyal sorumluluk raporlamasından kısa ve uzun dönemli faydaların kurumsal sosyal sorumluluk boyutları çerçevesinde tartışılması. Mubasebe Bilim Dünyası Dergisi,18 (Özel Sayı: I), 133-155.

Parlakkaya, R., Akmeşe, H. Akmeşe, K. (2016). Türk bankacılık sektöründe kurumsal sosyal sorumluluk raporlaması farkındalık düzeyi. Mubasebe Bilim Dünyası Dergisi, 18 (Özel Sayı: I), 881-896.

Sakarya, Ş. (2011). IMKB kurumsal yönetim endeksi kapsamındaki şirketlerin kurumsal yönetim derecelendirme notu ve hisse senedi getirileri arasındaki ilişkinin olay çalışması (EventStudy) yöntemi ile analizi. Uluslararası Yönetim İktisat ve İsletme Dergisi, 7(13), 147-162.

Sandeep, A. P., Balic, A. ve Bwakira, L. (2002). Measuring transparency and disclosure at firm-level in emerging markets. Emerging Market Review, 3 (4), 325-337.

Sayar, A. R. Z. ve Karataş, M. (2016). Şeffaflı̆̆ın sağlanmasında ve denetimin kalitesinin artırılmasında kamu gözetiminin rolü: Avrupa birliği ve üye ülkelerin uygulamaları. Muhasebe Bilim Dünyası Dergisi, 18(Özel Say1-1), 231-264.

Sevim, Ş. ve Şen, D. (2014). Kurumsal muhasebe derecelendirilmesi ve halka açı şirketlerde uygulaması. İşletme Arastermalar Dergisi, 6 (2), 148-178.

Tanç, Ş. G. ve Cingöz, A. (2011). Kurumsal yönetim ve çevresel performans: İMKB'de işlem gören şirketler üzerine bir araştırma. Mubasebe Bilim Dünyası Dergisi, 4, 203-219.

Terzi, S., Şen, İ. K. ve Solak, B. (2014). Kurumsal yönetim uygulamalarının denetim kalitesine etkisi: borsa İstanbul'da ampirik bir araştırma. Uluslararası Yönetim İktisat ve Issletme Dergisi, 10 (23), 191-206.

Tuna, A. K. (2013). Bankalarda kurumsal yönetim. Ankara: Nobel Yayınc1lik.

Türkiye Bankalar Birliği Bankacılık ve Araştırma Grubu, (2002). Şeffaflğ̆n Önemi Üzerine Bir Değerlendirme. Türkiye Bankalar Birliği Ocak 2002.

Uzay, Ş., Tanç, A. ve Erciyes, M. (2009). Türkiye'de muhasebe denetimi: Geçmişten geleceğe. Mali Çözüm Dergisi, 95 , 125-140.

Yanık, S. ve Türker, İ. (2012). Sürdürülebilirlik ve sosyal sorumluluk raporlamasındaki gelişmeler (Tümleşik raporlama). İstanbul Üniversitesi Siyasal Bilgiler Fakültesi Dergisi, 47, 291-308.

Yenice, S. ve T. Dölen. (2013). İMKB'de işlem göre firmaların kurumsal yönetim ilkelerine uyumunun firma değeri üzerine etkisi. Uluslararası Yönetim İktisat ve Issletme Dergisi, 9(19), 199-213.

\section{EXTENDED ABSTRACT}

In order to eliminate the business / accounting problems brought about by globalization, as well as accounting and financial reporting standards, it is necessary to ensure that managerial and financial information is sufficient and reliable in terms of both managerial and accounting issues and for all stakeholders, in other words, for enterprises to be accountable, transparent and institutionalized the corporate governance principles have been developed.

Public disclosure and transparency are the most important tools used in the surveillance and supervision of companies in the market economy. This also allows the public to be informed about the 
structures, activities and policies of the enterprises as well as their performance. However, the disclosures to be made by the company to the public should not cause any harm to the interests of the enterprise and should not lead to the disclosure of trade secrets about the business to the public. In order to ensure effective public disclosure, legal and administrative pressure on enterprises through laws and regulatory authorities alone will not be sufficient. Businesses should see that public disclosure can be the most effective way of attracting more long-term and permanent capital than a liability. The way to attract more long-term and patient patience is to provide the necessary trust to domestic and foreign investors. In order to establish trust in this regard, the company must be transparent and accountable.

According to the Corporate Governance Principles; Public Disclosure and Transparency is one of the principles included in the corporate governance framework, and it is aimed to ensure that the principles, including the financial status, performance and ownership structure of the enterprises, are made accurately and timely.

In order to provide transparency, informing the public by itself is not sufficient, and strict accounting rules are needed. The fact that information is reliable and comparable is closely related to the existence of effective rules and standards-based accounting practices that will enable companies to evaluate their activities and risk profiles on an equal basis.

The adoption of transparency and public disclosure at the enterprise level is important in terms of protecting investor rights and gaining public trust. Corporate transparency and public disclosure are directly related to accounting practices. As such, reliable, comprehensive, tailor-made and comparable financial statements can only be set by adopting internationally recognized Accounting / Financial Reporting Standards.

Mechanisms for increasing the transparency levels of enterprises can be listed as follows; independent audit, accounting and financial reporting standards, internal control and risk management, obligatory public disclosure obligation, non-financial reporting.

It should be noted that financial reports are the mirror of the enterprise and that the parties involved in the business make decisions about the business. Traditionally, the importance of accounting and the task that it is installed is put forward in this way. The enterprise management system of the enterprise is, in a sense, a set of rules that secure the provision of financial information provided to the interested parties.

It should be noted that Accounting and Financial Reporting Standards will be very important for the process in order to establish a transparent reporting system in the enterprises and to establish an accounting system. With the application of Accounting and Financial Reporting Standards by companies, reporting with quality and comparability characteristics can be made and the financial statements will be transparent, understandable, comparable and reliable. In this way, one of the important conditions of the institutionalization process, which has become a necessity for the enterprises that want to carry out their activities effectively and continuously, will be fulfilled and an important step will be taken in terms of establishing an effective accounting and financial reporting system in enterprises.

Transparency can arise as a result of a conscious responsibility, long-term objectives, consistent implementation of carefully-crafted policies. Transparency in this process requires constant updating in response to new market requirements and evolving organizational capabilities. Together with these features of transparency, there are of course factors affecting or triggering transparency. These factors, which may vary for each organization, will be considered on the basis of enterprises; It can be considered that the financial performance of enterprises has a possible effect on transparency and this argument constitutes the subject of the study.

In this study, the relationship between financial performance of enterprises and transparency and public disclosure levels were tried to be revealed. The companies included in the BIST XKURY Index (from Borsa Istanbul) were taken as a sample. Due to some constraints and uninterrupted data, a total of 115 observations were included in the total of 23 operations in a five-year period as a result of the elimination from these enterprises.

In order to represent the financial performance of the enterprises, the financial ratios of the enterprises are obtained; A standard financial performance score has been established for each entity through TOPSIS method. The calculated TOPSIS scores are considered to represent the financial performance of the relevant enterprises for this study. On the other hand, the Public Disclosure and 
Transparency Scores, which they presented in the activity reports, were taken into account in order to represent transparency and public disclosure levels.

In the study, firm sizes, firm borrowing rates and firm ages were used as control variables. In this respect, as independent variables of the model developed for testing the application of the study; TOPSIS scores, business size, borrowing rate (enterprise risk) and operating ages are included in the model.

It is possible to calculate the financial performance of a period (TOPSIS) in the middle of the following period. Since the disclosure of public disclosure and transparency notes also appeared recently, it was considered more plausible that the TOPSIS score for a period was related to the Public Disclosure and Transparency score of the following year. A similar approach was applied in other independent variables.

As a result of the analyses, it was found that the financial performance of the enterprises affected the public disclosure and transparency practices of the following year. It is observed that the firm size and firm borrowing ratio, which are included in the analysis together with the financial performance, also have an effect on public disclosure and transparency practices. It has been observed that firm size has a positive effect and firm borrowing rate has a negative effect. In addition, the firm age was included in the models in the model estimates but it did not have a significant effect on public disclosure and transparency practices.

As a result, there is evidence that the financial performance, size and borrowing rates of the enterprises may be explanatory for public disclosure and transparency practices of enterprises.

According to another result, no relationship was found between the age of the enterprise and the level of transparency and public disclosure. 